
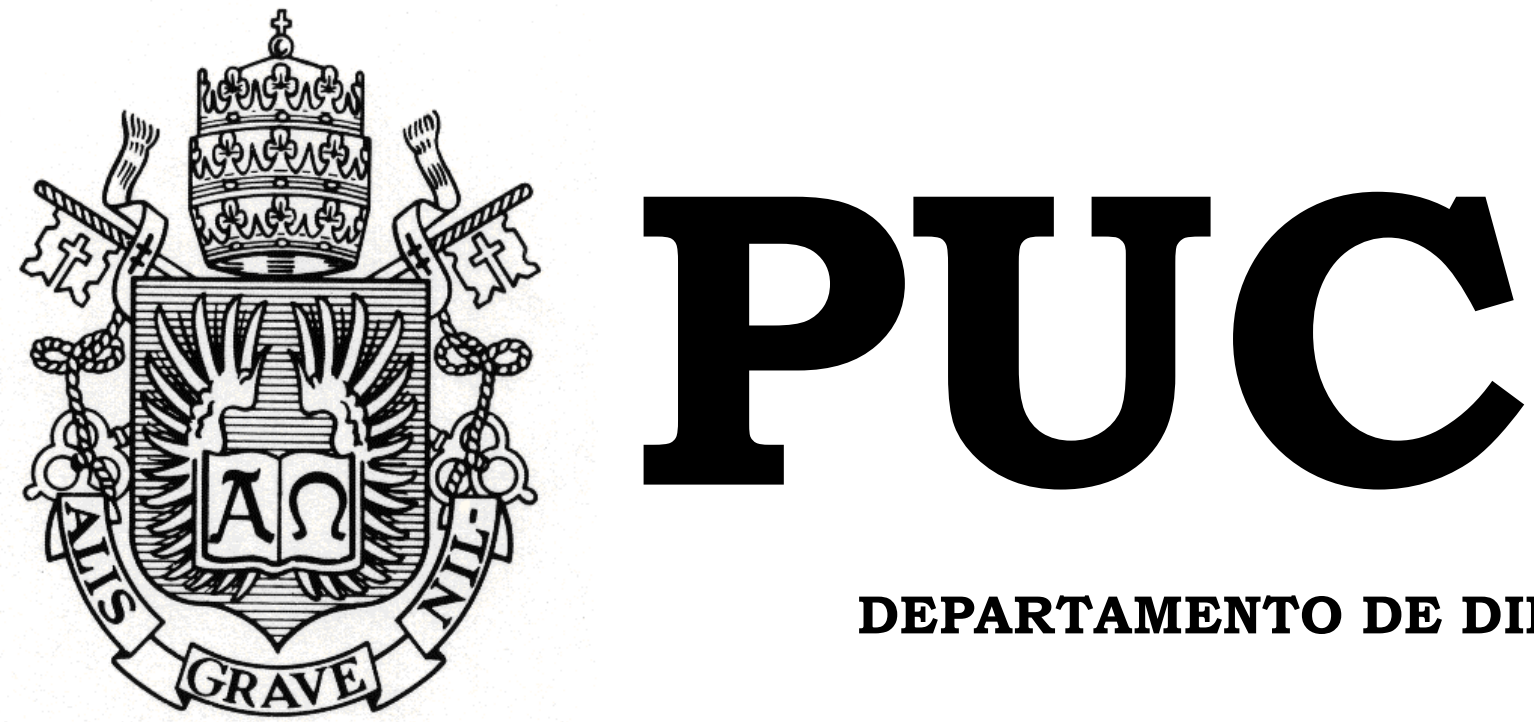

DEPARTAMENTO DE DIREITO

Paralelo Entre as Plataformas de Pagamento Online e as Atividades das Instituições Financeiras

$$
\text { por }
$$

JOÃO FELIPE PEREIRA GUIMARÃES ROCHA

ORIENTADOR(A): Norma Jonssen Parente

2013.2

PONTIFÍCIA UNIVERSIDADE CATÓLICA DO RIO DE JANEIRO

RUA MARQUÊS DE SÃO VICENTE, 225 - CEP 22453-900

RIO DE JANEIRO - BRASIL 


\title{
Paralelo Entre as Plataformas de Pagamento Online e as Atividades das Instituições Financeiras
}

\author{
por \\ JOÃO FELIPE PEREIRA GUIMARÃES ROCHA
Monografia apresentada ao Departamento de Direito da Pontificia Universidade Católica do Rio de Janeiro (PUC-Rio) para a obtenção do Título de Bacharel em Direito. \\ Orientador(a): \\ Norma \\ Jonssen Parente
}


Aos meus pais,

Ana Paula e Everardo, por todo o amor, carinho e dedicação empregados na minha criação, tanto como ser humano quanto profissional.

Aos meus irmãos,

Antonio e Zeca, que me ensinaram cada um em sua singularidade - lições valiosas de companheirismo e superação de diferenças.

Aos meus queridos amigos,

Francisco Müssnich e João Mansur, pelas inúmeras risadas e incontáveis histórias compartilhadas.

Ao meu chefe-amigo,

Vinicius Sahione, não só pela inestimável contribuição à este trabalho, mas principalmente pelos ensinamentos diários que ajudaram a moldar o profissional que sou.

À minha orientadora

Norma Parente, por ter acreditado neste projeto e pelos preciosos conselhos ao longo de sua realização. 


\section{RESUMO}

A presente monografia objetiva analisar se uma Plataforma de Pagamentos - instrumento utilizado quase que diariamente por milhares de brasileiros - pode ser considerado, devido a sua função (i.e., transferência dos recursos de um comprador a um vendedor), uma instituição financeira, de acordo com a legislação e doutrina brasileiras.

Para tanto, o Capítulo 1 faz trata do Sistema Financeiro Brasileiro, sua evolução histórica e principais entidades. A seguir, os capítulos 2 e 3 se propõem a definir os conceitos de instituição financeira e plataforma de pagamentos. Definidos tais conceitos, é realizada no Capítulo 4 uma comparação entre as atividades de uma plataforma de pagamentos e as atividades de uma instituição financeira, o que demonstra nosso entendimento sobre a análise objetivo deste trabalho. Por último, os Capítulos 5 e 6 o encerram demonstrando a principal consequência do entendimento exposto e outros aspectos jurídicos relevantes das Plataformas de Pagamento.

Palavras-chave: Plataforma de Pagamentos, E-commerce, Pagamentos Online, Instituições Financeiras, Sistema Financeiro Nacional, Lei de Usura, Chargeback, Direito de Regresso, Cadeia de Fornecimento, Responsabilidade Solidária. 


\section{Sumário}

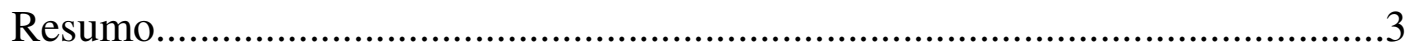

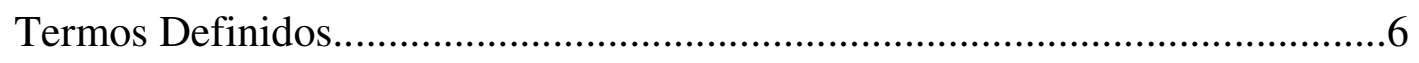

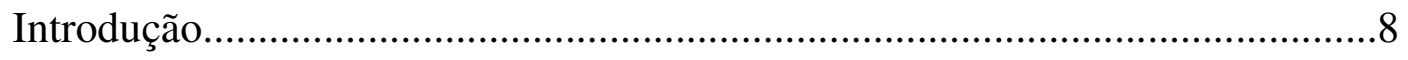

1. O Sistema Financeiro Nacional.............................................................10

1.1. Evolução Histórica..................................................................10

1.2. Entidades do Sistema Financeiro Nacional.....................................12

1.2.1. Conselho Monetário Nacional - CMN......................................12

1.2.2. Banco Central do Brasil - Bacen...............................................13

1.2.3. Comissão de Valores Mobiliários..............................................14

1.2.4. Banco do Brasil S.A...........................................................15

1.2.5. Banco Nacional de Desenvolvimento Econômico e Social -

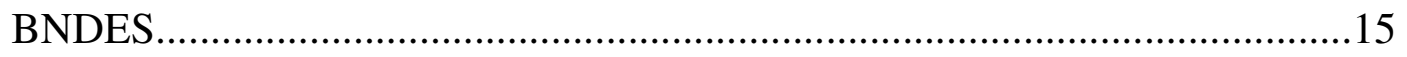

1.2.6. Instituições Financeiras..........................................................16

2. O Conceito de Instituição Financeira...........................................................18

2.1. O conceito de Instituição Financeira à luz da Legislação e Doutrina Brasileiras 18

2.2. A Lei do Colarinho Branco e a criminalização do exercício indevido de atividades financeiras.......................................................................22

3. Conceito de Plataforma de Pagamentos...................................................23

3.1. Significado de Plataforma de Pagamento.........................................23

3.2. Plataformas de Pagamento no Brasil...............................................24

3.3. Estrutura de Funcionamento da Plataforma de Pagamentos...............25

3.4. Relacionamento entre o Adquirente e a Plataforma de Pagamentos...28

3.5. Relacionamento entre o Vendedor e a Plataforma de Pagamento.....29

3.6. Relacionamento entre o Vendedor e o Adquirente. 30

4. A Plataforma de Pagamentos e a Sua Não Caracterização Como Instituição Financeira 
4.1. Características de Instituição Financeira vs. Plataformas de

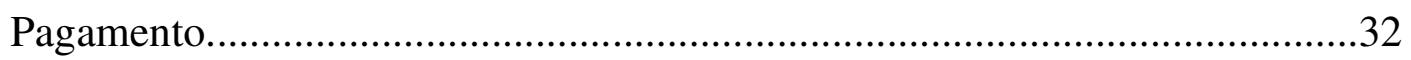

4.2. Exemplos de atividades não privativas de instituições financeiras e semelhantes às desempenhadas pela Plataforma de Pagamento.....................33

5. Limitação das Taxas das Plataformas de Pagamentos.................................34

6. Outros Aspectos Jurídicos Relevantes.....................................................38

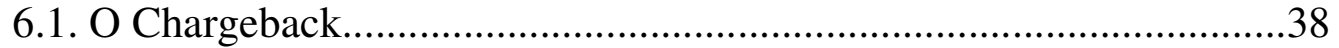

6.2. A utilização fraudulenta de cartão de

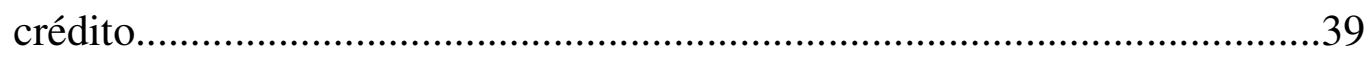

6.3. O Direito de Regresso............................................................41

6.4. A Hipótese da Responsabilidade Solidária do Vendedor e da Plataforma de Pagamentos...................................................................43

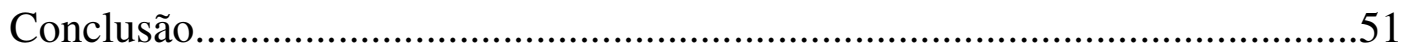

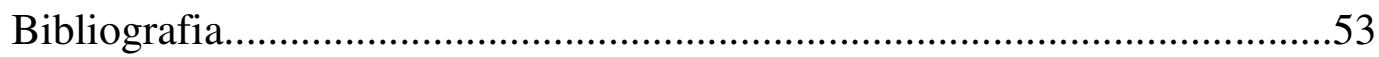

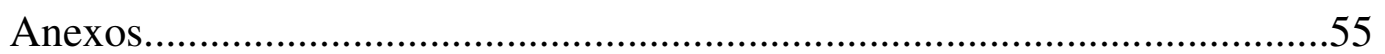




\section{Termos Definidos}

\begin{tabular}{|c|c|}
\hline Sistema Financeiro Nacional & Significa o sistema financeiro do Brasil. \\
\hline Lei do Sistema Financeiro Nacional & $\begin{array}{l}\text { Significa a Lei } \mathrm{n}^{0} 4.595 \text {, de } 31 \text { de } \\
\text { dezembro de } 1964 \text {, conforme alterada. }\end{array}$ \\
\hline $\mathrm{CMN}$ & $\begin{array}{llll}\text { Significa } & \text { o } & \text { Conselho } & \text { Monetário } \\
\text { Nacional. } & & & \\
\end{array}$ \\
\hline Bacen & Significa o Banco Central do Brasil. \\
\hline Banco do Brasil & Significa o Banco do Brasil S.A.. \\
\hline BNDES & $\begin{array}{l}\text { Significa o Banco Nacional do } \\
\text { Desenvolvimento Econômico e Social. }\end{array}$ \\
\hline Lei da CVM & $\begin{array}{l}\text { Significa a Lei } \mathrm{n}^{0} 6.385 \text {, de } 7 \text { de } \\
\text { dezembro de } 1976 \text {, conforme alterada. }\end{array}$ \\
\hline CVM & $\begin{array}{l}\text { Significa a Comissão de } \text { Valores } \\
\text { Mobiliários. }\end{array}$ \\
\hline Lei das Sociedades por Ações & $\begin{array}{l}\text { Significa a Lei } 6.404 \text {, de } 15 \text { de } \\
\text { dezembro de } 1976 \text {, conforme alterada. }\end{array}$ \\
\hline Resolução CMN 3.040 & $\begin{array}{l}\text { Significa a Resolução do CMN } \mathrm{n}^{\circ} \\
\text { 3.040, de } 28 \text { de novembro de } 2002 .\end{array}$ \\
\hline Resolução CMN 4.122 & $\begin{array}{l}\text { Significa a Resolução do CMN } \mathrm{n}^{\mathrm{o}} \\
\text { 4.122, de } 2 \text { de agosto de } 2012 .\end{array}$ \\
\hline Lei do Colarinho Branco & $\begin{array}{l}\text { Significa a Lei } n^{\circ} 7.492 \text {, de } 16 \text { de junho } \\
\text { de } 1986 \text {, conforme alterada. }\end{array}$ \\
\hline Plataformas de Pagamentos & $\begin{array}{l}\text { Significa as ferramentas por meio das } \\
\text { quais são realizadas compras online. }\end{array}$ \\
\hline Vendedor & $\begin{array}{l}\text { Significa o vendedor que utiliza a } \\
\text { Plataforma de Pagamentos para realizar } \\
\text { suas vendas online. }\end{array}$ \\
\hline
\end{tabular}




\begin{tabular}{|c|c|}
\hline Adquirentes & $\begin{array}{l}\text { Significa o indivíduo que realiza a } \\
\text { compra de determinado produto ou } \\
\text { serviço online, mediante a utilização de } \\
\text { uma Plataforma de Pagamentos. }\end{array}$ \\
\hline Credenciador & $\begin{array}{l}\text { Significa entidade responsável pelo } \\
\text { credenciamento de estabelecimentos } \\
\text { comerciais para aceitação de Bandeiras } \\
\text { de cartões. }\end{array}$ \\
\hline $\begin{array}{l}\text { Contrato de Prestação de Serviços } \\
\text { de Gestão de Pagamentos }\end{array}$ & $\begin{array}{l}\text { Significa o contrato de prestação de } \\
\text { serviços celebrado entre o Vendedor e a } \\
\text { Plataforma de Pagamentos. }\end{array}$ \\
\hline Taxas & $\begin{array}{llll}\text { Significa } & \text { as taxas cobradas } & \text { do } \\
\text { Vendedor } & \text { pelas Plataformas } & \text { de } \\
\text { Pagamento para a prestação } & \text { de } \\
\text { serviços. } & & & \\
\end{array}$ \\
\hline Lei de Usura & $\begin{array}{l}\text { Significa o Decreto } \mathrm{n}^{\circ} 22.626 \text {, de } 7 \text { de } \\
\text { abril de } 1933 \text {, conforme alterado. }\end{array}$ \\
\hline Código Civil Brasileiro & $\begin{array}{l}\text { Significa a Lei } \mathrm{n}^{\circ} 10.406 \text {, de } 10 \text { de } \\
\text { janeiro de } 2002 \text {, conforme alterada. }\end{array}$ \\
\hline $\mathrm{CDC}$ & $\begin{array}{l}\text { Lei } n^{\circ} 8.078 \text {, de } 11 \text { de setembro de } \\
1990 \text {, conforme alterada. }\end{array}$ \\
\hline
\end{tabular}




\section{Introdução}

A discussão de que trata este trabalho surgiu no dia-a-dia de um grande escritório de advocacia, durante a elaboração de um Contrato Social de uma Plataforma de Pagamentos. Ao ver o objeto social da sociedade, um dos participantes da operação levantou o seguinte questionamento: "Se a empresa faz transferência de recursos de um comprador ao vendedor, não seria ela uma instituição financeira e, portanto, não precisaria de autorização do Banco Central do Brasil para funcionar?”.

Após debates acalorados, optou-se pela interpretação doutrinária de instituição financeira e pelo entendimento de que a Plataforma de Pagamentos não poderia ser caracterizada como uma.

Este trabalho tem como objetivo "colocar por escrito" essas discussões, explicando os motivos deste entendimento e as consequências, para as Plataformas de Pagamentos, do mesmo.

Outro ponto importante que motivou a realização deste trabalho é a falta de informações e o esquecimento legislativo e doutrinário das Plataformas de Pagamentos. Como uma ferramenta utilizada diariamente por milhares de brasileiros pode ser tão ignorada? Não existem julgados sobre o assunto e não existe legislação ou resolução de nenhuma entidade que determine suas regras de constituição e funcionamento. Espera-se, portanto, que este trabalho chame a devida atenção a este ponto e fomente discussões sobre essas sociedades.

No primeiro capítulo, um pouco da história do sistema financeiro do Brasil é demonstrada, com sua evolução história até a estrutura atual e cada uma de suas principais entidades, com seus objetivos e atribuições. 
Já no segundo capítulo, será definido o conceito e os aspectos de uma instituição financeira. Primeiro é observada a definição legislativa (tanto da Lei do Sistema Financeiro Nacional quanto da Lei do Colarinho Branco) - um tanto simplória e ampla - e depois a doutrinária, que estabelece características objetivas e restritivas, quais sejam, basicamente, (i) intermediação especulativa; (ii) deve ser devedor do dinheiro captado e credor dos recursos emprestados; e (iii) interposição de forma profissional no crédito.

O terceiro capítulo, por sua vez, tem como intuito esclarecer o que são exatamente as Plataformas de Pagamentos. Para tanto, é demonstrada a estrutura e o fluxo do capital quando se é realizada uma compra online e cada um de seus atores e suas respectivas funções. Serão explicados, também o relacionamento dos três principais agentes da relação: o Adquirente, o Vendedor e a Plataforma de Pagamentos.

No quarto capítulo, são examinadas as características de uma Plataforma de Pagamentos vis-à-vis as de uma instituição financeira, para demonstração de como e porque foi entendido que as Plataformas de Pagamentos não podem ser caracterizadas como tal.

Encerrada a discussão sobre a caracterização das Plataformas de Pagamentos, os capítulos 5 e 6, objetivam demonstrar as consequências deste entendimento. $\mathrm{O}$ quinto capítulo trata da limitação da cobrança de taxas de remuneração pelas Plataformas de Pagamentos, considerando que a Lei de Usura e sua eventual aplicabilidade, enquanto o sexto capítulo trata de outros aspectos jurídicos relevantes, principalmente de cunho consumerístico, como o chargeback, o direito de regresso e a responsabilidade solidária em uma cadeia de fornecimento. 


\section{O Sistema Financeiro Nacional}

\subsection{Evolução Histórica}

Sistema financeiro pode ser definido, em linhas gerais, como um conjunto de instituições que tem como propósito garantir o fluxo de recursos entre poupadores e investidores.

O sistema financeiro do Brasil ("Sistema Financeiro Nacional"), da forma como conhecemos hoje, começou a ser estruturado pelo governo federal brasileiro por meio da Lei $\mathrm{n}^{0} 4.595$, de 31 de dezembro de 1964, conforme alterada ("Lei do Sistema Financeiro Nacional"). A Lei do Sistema Financeiro Nacional, em seu artigo $1^{\circ}$, estabelece que as entidades que o constituem são (i) o Conselho Monetário Nacional (“CMN”) ; (ii) o Banco Central do Brasil ("Bacen"); (iii) o Banco do Brasil S.A. ("Banco do Brasil"); (iv) o Banco Nacional do Desenvolvimento Econômico e Social ("BNDES"); e (v) as demais instituições financeiras públicas e privadas.

Após a regularização do funcionamento do Sistema Financeiro Nacional, houve um imediato crescimento do mercado de capitais brasileiro. Dessa forma, governo federal se viu diante da necessidade de normatizá-lo e fiscalizá-lo, principalmente quanto a atuação das sociedades de capital aberto. Foi então que, em 7 de dezembro de 1976, criou-se a Lei $n^{\circ}$ 6.385, conforme alterada ("Lei da CVM"), por meio da qual foi criada a Comissão de Valores Mobiliários ("CVM"), entidade governamental responsável pela regulamentação das atividades relacionadas ao mercado de capitais brasileiro (responsabilidade esta anteriormente atribuída ao Bacen). 
Ainda no ano de 1976, vale citar como importante inovação legislativa o advento, em 15 de dezembro, da Lei n” 6.404, conforme alterada ("Lei das Sociedades por Ações”), que, se não teve influencia direta na estruturação do Sistema Financeiro Nacional, tem grande importância no direito brasileiro por estabelecer regras claras quanto às características, forma de constituição, composição acionária e obrigações deste tipo societário.

As últimas grandes inovações legislativas que definiram a estrutura do Sistema Financeiro Nacional foram as Resoluções do CMN n ${ }^{\circ} 3.040$, de 28 de novembro de 2002 ("Resolução CMN 3.040”) e 4.122, de 2 de agosto de 2012 (“Resolução CMN 4.122”). A Resolução CMN 3.040 foi a primeira legislação a disciplinar os requisitos e procedimentos para a constituição, autorização para funcionamento e transferência de controle societário, bem como o cancelamento da autorização para funcionar, de instituições financeiras que passaram a precisar de prévia autorização do Bacen para funcionar. Já a Resolução CMN 4.122, apesar de revogar a Resolução CMN 3.040, tem o mesmo objeto e disciplina as mesma matéria desta.

Após todas estas mudanças e inovações, a estrutura atual simplificada do Sistema Financeiro Nacional é a que segue (a estrutura completa ${ }^{1}$ pode ser encontrada como Anexo A ao presente trabalho):

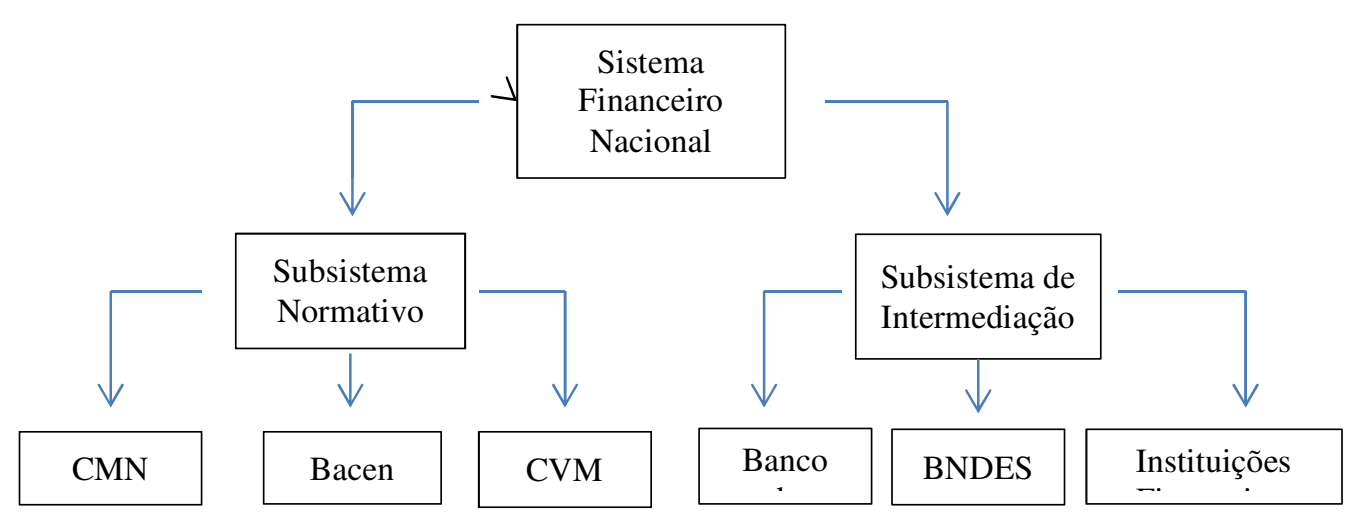

1 FORTUNA, Eduardo. Mercado Financeiro: produtos e serviços. $17^{\mathrm{a}}$ Ed.. Rio de Janeiro: Qualitymark, 2008.18 p. 


\subsection{Autoridades do Sistema Financeiro Nacional}

\subsubsection{Conselho Monetário Nacional - CMN}

O CMN é um órgão normativo por excelência e, portanto, não lhe cabem funções executivas. Esse órgão, apesar de já ter tido um número de membros variado ao longo de sua existência, hoje é composto por três membros: o Ministro da Fazenda, o Ministro de Planejamento, Orçamento e Gestão e o Presidente do Bacen (composição definida pela Medida Provisória $\mathrm{n}^{\mathrm{o}} 542$, de 30 de junho de 1994, que instituiu o Plano Real).

Ainda de acordo com a referida Medida Provisória, sua principal responsabilidade é fixar as diretrizes das políticas monetária e cambial do país. Para tanto, é de sua competência:

(i) regulamentar o valor interno e externo da moeda;

(ii) garantir condições favoráveis ao desenvolvimento da economia nacional;

(iii) zelar pela liquidez e solvência das instituições financeiras;

(iv) autorizar a emissão de papel-moeda;

(v) estabelecer a meta inflacionária; e

(vi) regular a constituição, o funcionamento e a fiscalização de todas as instituições financeiras que operam no país. 


\subsubsection{Banco Central do Brasil - Bacen}

O Bacen é o principal executor do orientações do Conselho Monetário Nacional (ou seja, cumpre e faz cumprir as disposições que regulam o Sistema Financeiro Nacional e as normas expedidas pelo $\mathrm{CMN}$ ) e o responsável por garantir o poder de compra da moeda nacional. O Bacen é conhecido como (i) "Emissor de Papel-moeda"; (ii) "Banqueiro dos Bancos"; (iii) "Banqueiro do Governo"; ou (iv) "Regulador do Sistema Financeiro Nacional", cada denominação sendo dada de acordo com uma de suas atribuições específicas.

O nome "Emissor de Papel-moeda" advém, obviamente, de seu monopólio na emissão de papel-moeda e cunhagem de moedas metálicas, além de sua capacidade de controlar a quantidade de papel-moeda em circulação.

Quando se refere ao Bacen como "Banqueiro dos Bancos", chama-se atenção ao fato de que ele "é o responsável pela compensação de cheques, realiza o transporte de cédulas e moedas metálicas aos bancos, mantém parte das reservas dos bancos, entre outras atividades de auxílio ao sistema bancário"2. Ademais, ele deve socorrer instituições financeiras em dificuldade, concedendo liquidez, principalmente por meio de empréstimos.

A denominação "Banqueiro do Governo" existe pois o Bacen é responsável pelo financiamento do Tesouro Nacional, pela administração da dívida pública, pela gestão das reservas internacionais do país e, finalmente, pela representação do Sistema Financeiro Nacional junto às instituições financeiras internacionais.

Finalmente, sua função mais importante para o presente trabalho e que lhe deu a nomenclatura de "Regulador do Sistema Financeiro Nacional": exercer a fiscalização das instituições financeiras, sendo inclusive 0 responsável pela autorização de funcionamento destas instituições. O Bacen ${ }^{2}$ CARVALHO, Fernando J. Cardim de et al.. Economia Monetária e Financeira. $3^{\circ}$ Ed.. Rio de
Janeiro: Editora Campus, 2001.102 p. 
também supervisiona as operações bancárias, de forma a evitar possíveis crises, podendo até impedir determinadas operações.

Em suma, "é por meio do Bacen que o Estado intervém no sistema financeiro e, indiretamente, na economia".

\subsubsection{Comissão de Valores Mobiliários - CVM}

Segundo a Medida Provisória $n^{0} 8$, de 31 de outubro de 2001, que alterou dispositivos da Lei da CVM, a mesma foi caracterizada como "entidade autárquica em regime especial, vinculada ao Ministério da Fazenda, com personalidade jurídica e patrimônio próprio, dotada de autoridade administrativa independente, ausência de subordinação hierárquica, mandato fixo e estabilidade de seus dirigentes, e autonomia financeira e orçamentária".

Seus objetivos são (i) assegurar o funcionamento eficiente e regular dos mercados de bolsa e de balcão; (ii) proteger os titulares de valores mobiliários contra emissões irregulares e atos ilegais de administradores e acionistas controladores de companhias ou de administradores de carteira de valores mobiliários; (iii) evitar ou coibir modalidades de fraude ou manipulação de valores mobiliários negociados no mercado; (iv) assegurar o acesso do público a informações sobre valores mobiliários negociados e as companhias que os tenham emitido; (v) assegurar a observância de práticas comerciais equitativas no mercado de valores mobiliários; e (vi) promover a expansão e o funcionamento eficiente e regular do mercado de ações.

A CVM é uma autoridade de apoio do Sistema Financeiro Nacional, que tem a responsabilidade de regular e fiscalizar o mercado de capitais brasileiro, especialmente no que tange às sociedades de capital aberto. 


\subsubsection{Banco do Brasil}

O Banco do Brasil foi fundado no ano de 1808, e é uma instituição financeira constituída na forma de sociedade de economia mista, com participação da União em pouco mais de $60 \%$ das ações.

Esta instituição financeira não atua apenas como banco múltiplo tradicional. O Banco do Brasil opera, em muitos casos, como agente financeiro do governo federal, sendo o principal operador da política oficial de crédito rural do governo federal e responsável pelo pagamento de suprimentos necessários à execução do Orçamento Geral da União, pela aquisição e financiamento dos estoques de produção exportável e pelo agenciamento dos pagamentos e recebimentos feitos fora do País. Além disso, ainda é o principal recebedor dos créditos do Tesouro Nacional e de quaisquer entidades federais.

\subsubsection{Banco Nacional de Desenvolvimento Econômico e Social - BNDES}

O BNDES foi fundado no ano de 1952, e é uma empresa pública federal, que funciona como instrumento de financiamento de longo prazo para a realização de investimentos em todos os segmentos da economia, com uma política que inclui as dimensões social, regional e ambiental.

Desde a sua fundação, o BNDES se destaca no apoio à agricultura, indústria, infraestrutura e comércio e serviços, oferecendo condições especiais para micro, pequenas e médias empresas. O Banco também vem implementando linhas de investimentos sociais, direcionados para educação e saúde, agricultura familiar, saneamento básico e transporte urbano.

O apoio do BNDES se dá por meio de financiamentos a projetos de investimentos, aquisição de equipamentos e exportação de bens e serviços. Além disso, ele atua no fortalecimento da estrutura de capital das empresas 
privadas e destina financiamentos não reembolsáveis a projetos que contribuam para o desenvolvimento social, cultural e tecnológico.

\subsubsection{Instituições Financeiras}

A função primária de uma instituição financeira é a realização de intermediação financeira indireta, ou seja, a transferência de fundos de agentes superavitários para deficitários. Explica-se: há sempre agentes econômicos que estão gerando excedente líquido (i.e., gerando mais renda do que o necessário para cobrir os gastos), enquanto há agentes econômicos que, de forma contrária, estão deficitários. O papel da instituição financeira é se colocar entre o poupador e aquele que precisa de recursos, "transportando" a poupança entre eles. Note-se que, desta forma, não há obrigação entre poupador e deficitário, mas sim entre cada um deles e a instituição financeira.

A Lei do Sistema Financeiro Nacional definiu, de forma extremamente vaga e simplória, instituições financeiras como "as pessoas jurídicas públicas ou privadas, que tenham como atividade principal ou acessória a coleta, intermediação ou aplicação de recursos financeiros próprios ou de terceiros". A doutrina brasileira, no entanto, com vistas a restringir essa ampla definição de instituição financeira, tem criado outras maneiras de definir se determinada entidade pode ser considerada instituição financeira ou não (vide Capítulo 2 abaixo).

E aqui cabe a questão que o presente trabalho pretende esclarecer: Seria uma Plataforma de Pagamentos (conforme definidas no capítulo 3 abaixo) uma instituição financeira e, dessa forma, regulada pelo CMN e Bacen? Conforme veremos detalhadamente abaixo, a Plataforma de Pagamentos transfere os recursos do Adquirente ao Vendedor (conforme abaixo definidos) e, portanto, faz a intermediação de recursos de terceiros. Assim, a simples leitura da legislação poderia levar a conclusão de que a Plataforma de Pagamentos é sim uma instituição financeira. No entanto, antes de darmos como encerrada a 
questão, faz-se necessária uma análise da definição doutrinária de uma instituição financeira e das atividades de uma Plataforma de Pagamentos. 


\section{O CONCEITO dE INSTITUIÇÃo FinANCEIRA}

\subsection{O conceito de Instituição Financeira à luz da Legislação e Doutrina Brasileiras}

As instituições financeiras, tendo em vista o seu grau de importância para a poupança popular e para o fomento da economia nacional, são reguladas por diversos diplomas legais e regulamentares e supervisionadas pelo Bacen. Conceitualmente, a Lei do Sistema Financeiro Nacional, estabeleceu que:

"Art. 17. Consideram-se instituições financeiras, para os efeitos da legislação em vigor, as pessoas jurídicas públicas ou privadas, que tenham como atividade principal ou acessória a coleta, intermediação ou aplicação de recursos financeiros próprios ou de terceiros, em moeda nacional ou estrangeira, e a custódia de valor de propriedade de terceiros.

Parágrafo único. Para os efeitos desta lei e da legislação em vigor, equiparam-se às instituições financeiras as pessoas físicas que exerçam qualquer das atividades referidas neste artigo, de forma permanente ou eventual."

Dispõe essa lei, ainda, que o funcionamento de instituições financeiras no Brasil está sujeito à autorização prévia do Bacen.

Como se pode observar, a legislação pertinente às instituições financeiras conceituou-as de forma extremamente ampla e, se interpretada literalmente, poucas empresas ou mesmo pessoas físicas no Brasil escapariam da definição de instituições financeiras.

Não por outro motivo, essa definição é alvo de críticas generalizadas por parte da doutrina brasileira, como, por exemplo, de Nelson Eizirik, para quem: 
"se interpretado literalmente o art. 17 da Lei 4.595/64, poderia ser considerada instituição financeira qualquer pessoa que aplicasse até mesmo recursos próprios, $o$ que se daria um evidente absurdo jurídico."

A doutrina vem adotando, como forma de suprir a lacuna existente no arcabouço legal pátrio, uma interpretação finalista dos citados dispositivos legais, buscando o intuito da norma e analisando-a sob este enfoque.

Nessa linha, parece elucidativo o modo pelo qual Eizirik ${ }^{4}$ elenca os elementos básicos para a caracterização jurídica da intermediação financeira, elemento central das atividades prestadas por instituições financeiras, a saber: (i) a ocorrência de intermediação especulativa, onde o intermediador capta 0 dinheiro alheio e o vende, com juros, a uma taxa superior à da captação, para

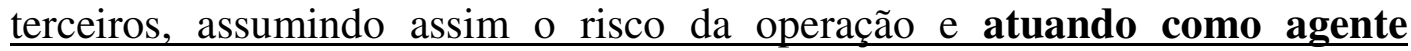
multiplicador do meio circulante; (ii) a participação na cadeia obrigacional, de forma que o intermediador deve ser devedor do dinheiro captado e credor dos recursos emprestados; e (iii) deverá haver interposição de forma profissional no crédito, caracterizando a sua negociação, uma vez que $\underline{\text { meramente tomar ou emprestar dinheiro não é atividade privativa de instituição }}$ financeira.

Da mesma forma complementa Eduardo Salomão, quando define que se exige das instituições financeiras, cumulativamente, (i) a captação de $\underline{\text { recursos de terceiros em nome próprio; }}$ (ii) seguida de repasse financeiro $\underline{\text { através de operação de mútuo }}^{5}$; (iii) com o intuito de auferir lucro derivado da maior remuneração dos recursos repassados em relação aos recursos

\footnotetext{
${ }^{3}$ EIZIRIK, Nelson. Administração de cartão de crédito constitui atividade privativa de instituição financeira? Revista de Direito Mercantil, Industrial, Econômico e Financeiro. São Paulo: RT, 1992, n. $88,27 \mathrm{p}$.

${ }^{4}$ EIZIRIK, Nelson. Administração de cartão de crédito constitui atividade privativa de instituição financeira? Revista de Direito Mercantil, Industrial, Econômico e Financeiro. São Paulo: RT, 1992, n. 88, $27 \mathrm{p}$.

${ }^{5}$ Em breves palavras, o contrato de mútuo é aquele em que se empresta coisa fungível, ou seja, algo que possa ser substituído, tal como o dinheiro.
} 
$\underline{\text { coletados; }}$ e (iv) desde que a captação seguida de repasse se realize em caráter habitual $^{6}$.

Por fim, e como último elemento caracterizador das instituições financeiras, deve-se restar configurado o intuito de lucro pelas sociedades, uma vez que um dos pilares para se configurar uma sociedade empresarial no Brasil é a geração de capital para seus acionistas e quotistas.

\subsection{A Lei do Colarinho Branco e a criminalização do exercício indevido de atividades financeiras}

Quanto ao exercício indevido de atividades estritamente financeiras, a Lei $\mathrm{n}^{\mathrm{o}}$ 7.492, de 16 de junho de 1986, conforme alterada ("Lei do Colarinho Branco"), que define os crimes contra o Sistema Financeiro Nacional, veio a tipificar como delito penal determinadas condutas que podem por em risco a higidez e a boa administração das instituições financeiras.

Nesse sentido, o legislador optou por criminalizar, por meio do artigo 16 da referida lei, o exercício das atividades privativas de instituições financeiras, inclusive de distribuição de valores mobiliários ou de câmbio, quando estas forem realizadas sem a devida autorização do Bacen (ou mediante declaração falsa $)^{7}$.

Salientamos que, em razão da sua posterioridade, o conceito de instituição financeira, para fins da Lei do Colarinho Branco, possui algumas especificidades adicionais àquelas trazidas pela Lei do Sistema Financeiro Nacional, as quais serão abordadas a seguir.

$\mathrm{O}$ artigo $1^{\circ}$ da Lei do Colarinho Branco estabelece que:

\footnotetext{
${ }^{6}$ NETO, Eduardo Salomão. Direito Bancário. $1^{\circ}$ Ed.. São Paulo, Editora Atlas, 27 p.

7 “Art. 16. Fazer operar, sem a devida autorização, ou com autorização obtida mediante declaração (Vetado) falsa, instituição financeira, inclusive de distribuição de valores mobiliários ou de câmbio: Pena - Reclusão, de 1 (um) a 4 (quatro) anos, e multa."
} 
"Art. $1^{\circ}$ Considera-se instituição financeira, para efeito desta lei, a pessoa jurídica de direito público ou privado, que tenha como atividade principal ou acessória, cumulativamente ou não, a captação, intermediação ou aplicação de recursos financeiros de terceiros, em moeda nacional ou estrangeira, ou a custódia, emissão, distribuição, negociação, intermediação ou administração de valores mobiliários.

Parágrafo único. Equipara-se à instituição financeira:

I - a pessoa jurídica que capte ou administre seguros, câmbio, consórcio, capitalização ou qualquer tipo de poupança, ou recursos de terceiros;

II - a pessoa natural que exerça quaisquer das atividades referidas neste artigo, ainda que de forma eventual." (grifos nossos)

A formulação do conceito de atividade de instituição financeira se assemelha bastante ao que prevê o artigo 17 da Lei Sistema Financeiro Nacional, mas com três diferenças básicas, senão vejamos:

(i) a captação, intermediação ou aplicação de recursos financeiros podem se dar de maneira cumulativa ou não;

(ii) a captação, intermediação ou aplicação somente gera o enquadramento como instituição financeira em caso de se referirem a recursos de terceiros ${ }^{8}$;

(iii) não só a custódia de valores mobiliários é qualificada como atividade privativa, mas também a sua emissão, distribuição, negociação, intermediação ou administração.

Dessa forma, pode-se dizer que não há necessidade, como no caso da Lei do Sistema Financeiro Nacional, que a captação e/ou a aplicação de recursos se dê de maneira cumulativa, pois também podem ser consideradas

\footnotetext{
${ }^{8}$ Uma incongruência sanada pela Lei do Colarinho Branco quanto à Lei no ${ }^{\circ} .595$, pois não é possível a captação ou intermediação de recursos próprios tal como dispunha o diploma legal anterior.
} 
instituições financeiras para fins daquela lei as sociedades que realizem, individualmente, qualquer uma delas ${ }^{9}$.

A Lei do Colarinho Branco, ainda, restringiu à custódia de valores mobiliários apenas, além da nova redação sobre a sua emissão, distribuição, negociação, intermediação ou administração, atividades essas que levariam à caracterização de uma sociedade como instituição financeira.

Superados os esclarecimentos a respeito das novidades trazidas pela Lei do Colarinho Branco, registre-se que a interpretação doutrinária relativa ao conceito de instituição financeira disposta na Lei do Sistema Financeiro Nacional também se aplica à sua congênere penal, principalmente ao critério habitual e de intuito de lucro ${ }^{10}$.

Conclui-se que a Lei do Colarinho Branco (i) tem por objetivo tipificar delitos criminais sempre que determinada situação prevista seja verificada; (ii) não altera o conceito legislativo previsto no artigo 17 da Lei do Sistema Financeiro Nacional, tampouco sua construção doutrinária; e (iii) prevê a criminalização de condutas por agentes que não sejam considerados, necessariamente, instituição financeira nos moldes da Lei do Sistema Financeiro Nacional, desde que se enquadrem em sua definição mais ampla ${ }^{11}$.

\footnotetext{
${ }^{9}$ Assim, os administradores de fundos de investimento ou de carteiras de valores mobiliários, que aplicam recursos de terceiros e podem ser pessoas físicas ou jurídicas, também serão considerados instituições financeiras.

${ }^{10}$ NETO, Eduardo Salomão. Direito Bancário. $1^{\circ}$ Ed.. São Paulo, Editora Atlas. 479 p.

${ }^{11}$ Como é o caso, por exemplo, do artigo 20 da Lei do Colarinho Branco, que criminaliza "Aplicar, em finalidade diversa da prevista em lei ou contrato, recursos provenientes de financiamento concedido por instituição financeira oficial ou por instituição credenciada para repassá-lo: Pena - Reclusão, de 2 (dois) a 6 (seis) anos, e multa".
} 


\section{Conceito de Plataforma de Pagamentos}

\subsection{Significado de Plataforma de Pagamento}

O Ministério da Justiça do Brasil, por meio de sua Secretaria de Direito Econômico - SDE, no âmbito do Procedimento Administrativo 08012.004089/2009-01, conceituou a Plataforma de Pagamentos (também conhecida como facilitadora de pagamentos) como sendo aquela sociedade que:

"opera no comércio eletrônico oferecendo, entre outros serviços, a possibilidade de que, de um lado, usuários cadastrados em seu site realizem transações eletrônicas sem precisar repassar às lojas virtuais suas informações financeiras (tais como a conta bancária ou o número do cartão de crédito) e, de outro, fornecedores recebam os pagamentos sem precisarem se credenciar junto às diferentes credenciadoras de cartão de crédito. Exemplos dos chamados "facilitadores" são o Paypal (Ebay), MercadoPago (MercadoLivre), PagSeguro (UOL) e Pagamento Digital".

Explica-se: as Plataformas de Pagamento são as ferramentas por meio das quais são realizadas compras online. Quando um indivíduo realiza uma compra online, o site do vendedor, por meio da qual ele está adquirindo o serviço ou produto o direciona para uma outra página, na qual ele irá inserir os dados de seu cartão e irá finalizar o pagamento ("Plataforma de Pagamentos").

A Plataforma de Pagamentos faz o "meio de campo" entre comprador e vendedor (ou prestador de serviços, conforme o caso). De forma resumida, a Plataforma de Pagamentos recebe os recursos do comprador e os repassa para o vendedor. Para o comprador, este serviço permite que ele faça seu pagamento sem ter que fornecer informações financeiras para a loja, enquanto para o vendedor a vantagem é que ele não precisa se contratar individualmente com cada Credenciador (conforme abaixo definido) - somente com a 
Plataforma de Pagamentos - para oferecer aos seus clientes a possibilidade de realizar compras online com cartões de bancos e bandeiras diversas.

Além das Plataformas de Pagamento Paypal, Mercado Pago, Pagseguro e Pagamento Digital citadas pelo Ministério da Justiça, ainda existem no mercado brasileiro a Cobre Bem, Moip, Allpago, Braspag, MaxiPago, Payzen, entres outras, o que demonstra o grande crescimento do $e$-commerce (comércio online) no Brasil.

\subsection{Plataformas de Pagamento no Brasil}

As Plataformas de Pagamento, há muito tempo presentes no exterior, surgiram no Brasil em razão, de um lado, da crescente demanda do consumidor brasileiro com relação ao mercado e-commerce, e, de outro, das medidas de prevenção tomadas por compradores e vendedores contra potenciais fraudes, principalmente no caso do uso ilícito de cartões de crédito furtados e cheques sem fundo. Ainda, e especificamente quanto ao mercado eletrônico, há o natural receio por parte do comprador quanto à verdadeira origem do vendedor e, também, por parte do vendedor, com relação às tantas hipóteses de pagamentos fraudulentos, situações que podem inibir tanto a aquisição quanto a venda pela internet.

A Plataforma de Pagamentos viabiliza a entrada de pequenas e médias empresas no e-commerce ao fornecer uma ampla variedade de alternativas de pagamento aos vendedores, bem como a possibilidade de parcelamento das compras realizadas, o que beneficia o comprador.

No que se refere aos modelos de negócios adotados pelas Plataformas de Pagamentos, pode-se dizer que estão divididos, basicamente, em duas estruturas, sendo a primeira baseada em uma cobrança de taxa ao vendedor e, a 
segunda, em uma do comprador, as quais serão abordadas resumidamente a seguir ${ }^{12}$.

No primeiro modelo, isto é, o "modelo de cobrança do vendedor", ocorre a cobrança de taxa pela utilização da Plataforma de Pagamentos da loja virtual (i.e., do vendedor) no momento em que a Plataforma de Pagamentos transfere os recursos recebidos em nome do comprador, ou seja, esta repassa ao vendedor o preço do bem e/ou serviço (já descontadas todas as taxas incidentes no processo, tais como as referentes ao Credenciador) subtraída a tarifa relativa a todo o pacote de serviços que oferece.

No "modelo de cobrança do comprador", o vendedor fica isento da taxa pela utilização dos serviços disponíveis, a qual recai sobre o comprador. Neste caso, a Plataforma de Pagamentos repassa ao vendedor o valor integral da transação (descontadas apenas as taxas incidentes no processo, tais como as referentes ao Credenciador).

\subsection{Estrutura de Funcionamento da Plataforma de Pagamentos}

A estrutura contratual de uma Plataforma de Pagamentos baseia-se na habilitação de seu usuário, que mantém uma conta ativa junto à Plataforma de Pagamento ("Vendedor"), como ferramenta de recebimento de pagamentos decorrentes da venda de bens e/ou de prestação de serviços a seus clientes (esses compradores do Vendedor, os "Adquirentes" ou, individualmente, "Adquirente").

A estrutura abaixo ilustra o funcionamento da Plataforma de Pagamentos e identifica as principais partes envolvidas:

\footnotetext{
${ }^{12}$ Existem no Brasil, ainda, modelos híbridos que cobram taxas tanto dos vendedores, quanto dos compradores.
} 


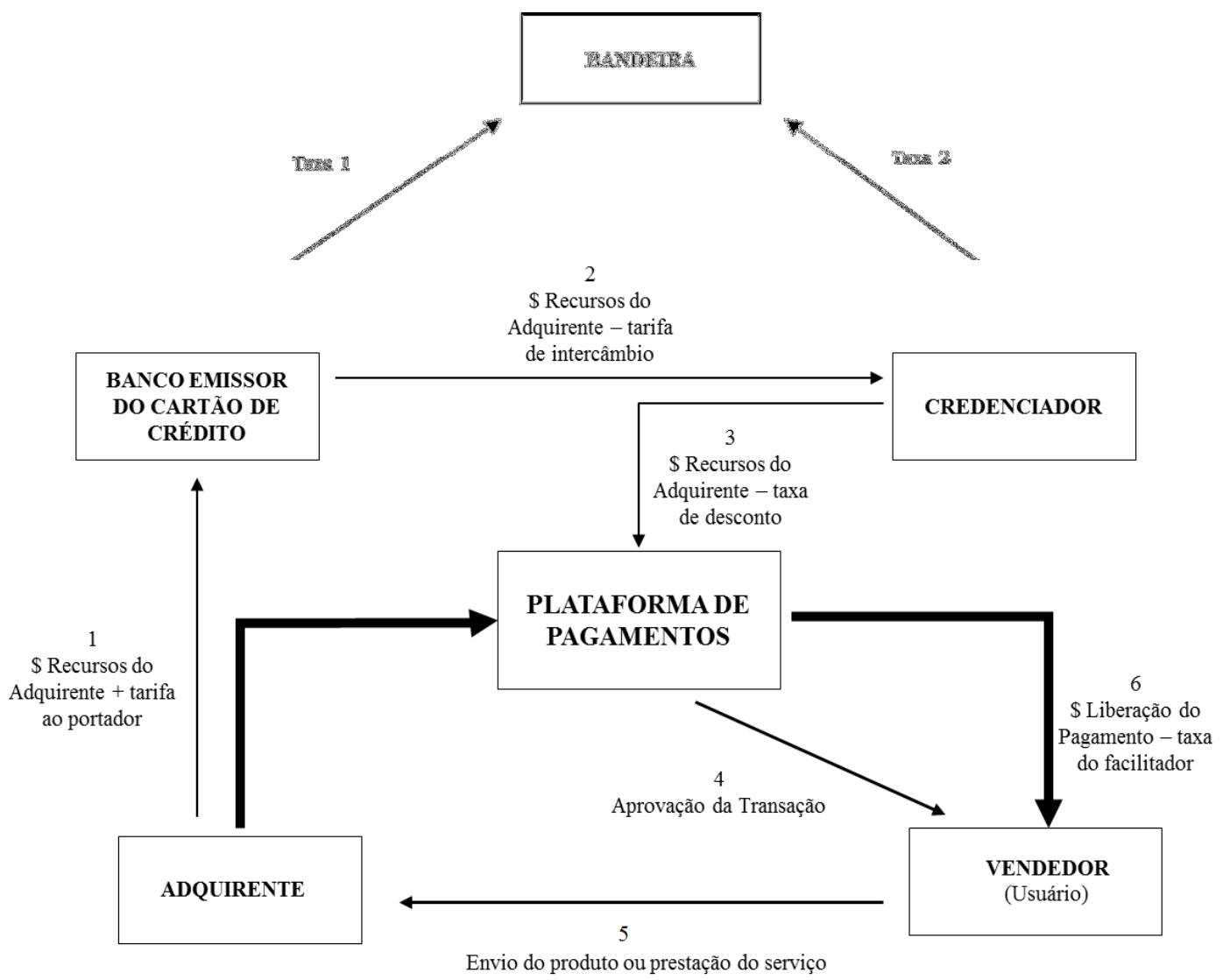

No esquema acima, as setas em destaque mostram o relacionamento Adquirente - Plataforma de Pagamentos - Vendedor, enquanto as demais setas mostram o fluxo dos recursos do Adquirente no momento em que uma compra online é finalizada.

Para melhor demonstrar o funcionamento deste sistema, vamos caracterizar individualmente seus atores e suas respectivas funções:

(i) O "Adquirente" é o indivíduo que realiza a compra de determinado produto ou serviço online, mediante a utilização de uma Plataforma de Pagamentos;

(ii) "Banco Emissor" é a instituição financeira autorizada a emitir cartões de pagamento de determinada Bandeira. É o responsável 
primário pela relação com o portador do cartão de pagamento, quanto à habilitação, identificação, autorização, limite de crédito ou saldo em conta corrente e cobrança de fatura;

(iii) "Bandeira" é a empresa nacional ou estrangeira detentora dos direitos de propriedade e franqueadoras de suas marcas, mediante a especificação de regras gerais de organização e funcionamento dos cartões. Exemplos de Bandeiras: Visa e Mastercard.

(iv) "Credenciador" é a entidade responsável pelo credenciamento de estabelecimentos comerciais para aceitação de Bandeiras de cartões ("Credenciador");

(v) "Plataforma de Pagamentos" é a ferramenta online que permite a realização das transações online (conforme melhor definida no item 3.1 acima); e

(vi) "Vendedor" é aquele que oferta produtos ou serviços online, e, para tanto, contrata a Plataforma de Pagamentos para realizar a transação dos recursos do Adquirente.

Nesta estrutura, a Plataforma de Pagamentos tem como funções a criação de ferramenta online, segura e confiável, que permite que os Adquirentes informem as informações de seus cartões sem que essas informações se tornem públicas, a contratação com diversos Credenciadores, para que as compras possam ser realizadas com cartões de variadas bandeiras (ao contrário de estabelecimentos físicos que contratam individualmente com os Credenciadores das bandeiras que desejarem, motivo pelo qual as vezes certos estabelecimentos só aceitam determinada bandeira específica), e, finalmente, a realização do repasse dos recursos dos Adquirentes aos Vendedores. 


\subsection{Relacionamento entre o Adquirente e a Plataforma de Pagamentos}

O relacionamento entre o Adquirente e a Plataforma de Pagamentos se inicia no momento da aceitação, pelo Adquirente, dos termos de uso da Plataforma de Pagamentos (o famoso "li e aceito as condições"), que estabelece, entre outras, a obrigação da Plataforma de Pagamento de repassar ao Vendedor os recursos que lhe são entregues pelo Adquirente no âmbito de transações comerciais online.

Nesse sentido, o Adquirente utiliza a Plataforma de Pagamentos exclusivamente para que a mesma, na qualidade de intermediadora e repassadora de recursos, faça a operação de repasse de recursos de forma segura entre ele e o alienante dos bens e/ou prestador dos serviços disponíveis online.

A relação jurídica entre o Adquirente e a Plataforma de Pagamentos se inicia com a adesão aos termos e condições de uso e a realização do pagamento por meio da Plataforma de Pagamentos. Já o seu encerramento se dá no momento em que a obrigação de remeter os recursos à Plataforma de Pagamentos se extingue (seja nos casos em que o Adquirente efetua a totalidade do pagamento de maneira imediata, seja nos casos do pagamento parcelado), constituindo-se uma relação de cunho obrigacional com prazo determinado.

\subsection{Relacionamento entre o Vendedor e a Plataforma de Pagamento}

O relacionamento entre o Vendedor e a Plataforma de Pagamento se dá por meio da celebração de contrato de prestação de serviços para vendedor (“Contrato de Prestação de Serviços de Gestão de Pagamentos”), sendo que o 
Vendedor que celebrar este Contrato de Prestação de Serviços de Gestão de Pagamentos receberá da Plataforma de Pagamento os pagamentos do Adquirente por conta e ordem deste (para maiores informações sobre as disposições deste tipo de contrato, vide o "Instrumento Particular de Prestação de Serviços de Gestão de Pagamentos e Outras Avenças" da Akatus Meios de Pagamento S.A., que consta como $\underline{\text { Anexo B }}$ a este trabalho) ${ }^{13}$.

A relação contratual entre o Vendedor e a Plataforma de Pagamento se resume a uma relação de prestação de serviços, por meio da qual a Plataforma de Pagamentos disponibiliza seus serviços para que o Vendedor possa oferecer a seus clientes diferentes formas de pagamentos operacionalizadas pela Plataforma de Pagamentos. O Vendedor não precisa recorrer individualmente a cada uma das administradoras de cartão de crédito e instituições bancárias para a celebração de convênios, o que the possibilita gerenciar seu fluxo de recebíveis com maior facilidade e agilidade.

Os valores pagos pelo Adquirente à Plataforma de Pagamento permanecerão bloqueados em conta de titularidade desta e em nome de cada Vendedor, podendo o tempo de repasse destes valores variar dependendo do prazo estabelecido no Contrato de Prestação de Serviços de Gestão de Pagamentos.

Como remuneração pela prestação dos serviços acima descritos, a Plataforma de Pagamentos recebe um valor fixo por cada transação efetuada, além de uma porcentagem sobre valores a serem recebidos pelo Vendedor, que irá variar dependendo do tempo de repasse desses recursos (quanto menor o tempo de repasse, maior o abatimento suportado pelo Vendedor) ("Taxas"). Apesar de cada Plataforma de Pagamentos cobrar as Taxas de sua maneira, cita-se, a título exemplificativo, as formas de remuneração oferecidas

\footnotetext{
${ }^{13}$ Informação retirada do site da Akatus Meios de Pagamento S.A., acessível por meio do seguinte endereço eletrônico: https://site.akatus.com/como-funciona
} 
pela Akatus Meios de Pagamento S.A., a qual oferece os seguintes pacotes ${ }^{14}$ de remuneração ao vendedor que a contrata:

(i) Prazo de 30 dias: O Vendedor suportará um abatimento de 3,99\% em todas as vendas com cartões de crédito e 1,89\% em boleto bancário e débito online;

(ii) Prazo de 14 dias: O Vendedor suportará um abatimento de 4,99\% em todas as vendas com cartões de crédito e 2,19\% em boleto bancário e débito online; e

(iii) Prazo de 2 dias: O Vendedor suportará um abatimento de 6,4\% em todas as vendas com cartões de crédito e $2,89 \%$ em boleto bancário e débito online.

Por fim, nos pacotes da Akatus Meios de Pagamento S.A., o Vendedor ainda suportará, do valor total a ser recebido, o custo por transação efetuada de $\mathrm{R} \$ 0,39$.

\subsection{Relacionamento entre o Vendedor e o Adquirente}

A relação contratual entre o Vendedor e o Adquirente, por ser eventual e espontânea, pode ser considerada como uma relação de compra e venda e/ou prestação de serviços, com a característica peculiar de que, em virtude do Contrato de Prestação de Serviços de Gestão de Pagamentos firmado entre o Vendedor e a Plataforma de Pagamento, aquele não pode se contrapor à realização do pagamento pelos meios oferecidos na Plataforma de Pagamentos.

\footnotetext{
${ }^{14}$ Informação retirada do site da Akatus Meios de Pagamento S.A., acessível por meio do seguinte endereço eletrônico: https://site.akatus.com/como-funciona. Acesso em 10 de outubro de 2013.
} 


\section{A Plataforma de Pagamentos e a Sua Não Caracterização Como Instituição Financeira}

\subsection{Características de Instituição Financeira vs. Plataformas de Pagamento}

Para uma eventual imputação das atividades da Plataforma de Pagamentos como restritas às instituições financeiras, cumpre analisar abaixo cada um dos elementos configuradores de uma instituição financeira (conforme estabelecidos no Capítulo 2 acima) vis-à-vis as atividades desempenhadas pelas Plataformas de Pagamentos:

(i) Coleta e aplicação de recursos de terceiros: a Plataforma de Pagamentos, não coleta junto ao público em geral recursos, tampouco os aplica em investimentos financeiros, mas tão somente recebe os recursos do Adquirente e os repassa, no âmbito de uma prestação de serviços, à pessoa a quem tem direito de recebê-los, isto é, o Vendedor;

(ii) Operação de mútuo: não há que se falar em repasse de valores sob a forma de empréstimo, considerando que a Plataforma de Pagamento não se torna devedora do Adquirente e/ou credora dos Vendedores, tampouco os repassa sob a forma de qualquer operação de crédito ou financeira;

(iii) Interposição profissional: não há interposição de forma profissional para os fins da legislação bancária, pois não resta caracterizado o binômio captação de recursos - concessão de crédito. A Plataforma de Pagamentos apenas repassa, após deduzidas as Taxas, os recursos recebidos do Adquirente ou ao 
Vendedor, sem que tal operação caracterize captação de recursos junto ao público ou concessão de empréstimos ou mútuos;

(iv) Intermediação especulativa: a Plataforma de Pagamentos não capta dinheiro alheio e o vende, com juros, a terceiros, não atuando, assim, como agente multiplicador do meio circulante; e

(v) Intuito de lucro: as operações realizadas por meio da Plataforma de Pagamento têm como objetivo o lucro uma vez se tratar a Plataforma de Pagamentos de uma sociedade empresária, fato que não tem o condão, isoladamente, de qualificar a Plataforma de Pagamento como uma instituição financeira.

Pode-se concluir que as atividades da Plataforma de Pagamento não são privativas de instituição financeira e, dessa forma, não estão sujeitas à prévia autorização do Bacen.

\subsection{Exemplos de atividades não privativas de instituições financeiras e semelhantes às desempenhadas pela Plataforma de Pagamento}

Do ponto de vista regulatório, a intermediação de pagamento pelas Plataformas de Pagamentos assemelha-se bastante aos correspondentes bancários $^{15}$, os quais prestam serviços, dentre outros, de arrecadação de boletos de pagamento (como contas de água e telefone) para repasse às instituições financeiras e estas, por sua vez, aos credores dos títulos (como as concessionárias de serviços públicos). Os correspondentes bancários não

\footnotetext{
${ }^{15}$ Em resumo, a contratação de correspondentes bancários (tais como as Lotéricas), por instituições financeiras, é regulada pela Resolução n ${ }^{\circ} 3.954$, de 24 de fevereiro de 2011, conforme alterada. Como dispõe a referida regulamentação, os correspondentes bancários não necessitam ser entidades do Sistema Financeiro Nacional, nem dependem de prévia autorização do Bacen para operar.
} 
necessitam ser entidades do Sistema Financeiro Nacional, nem dependem de autorização do Bacen para operar.

Mais semelhante ainda é a atividade desempenhada pelo próprio Credenciador em certos casos, a qual não requer a autorização do Bacen ou se configura como instituição financeira. Isto porque o Credenciador, em certos casos não apenas repassa os recursos, mas realiza verdade atividade de "desconto mercantil" ou de "antecipação de pagamento", mediante uma taxa estipulada, nas hipóteses em que o estabelecimento comercial opta por recebêlos previamente à data estipulada.

Nesse caso, o estabelecimento comercial, por razões econômicas, solicita o adiantamento dos recursos a serem recebidos em determinada data (a qual, normalmente, se dá em 30 ou 31 dias) e aceita a imputação de um desconto calculado com base no tempo de maturidade - ou vencimento - do crédito devido, prática considerada praxe usual no mercado. Não se pode confundir, todavia, o "desconto mercantil" com o desconto bancário de duplicatas, esta sim operação privativa de instituição financeira, mesmo porque simplesmente não há, no caso, qualquer emissão de duplicatas, como é requerido naquele desconto ${ }^{16}$.

\footnotetext{
${ }^{16}$ EIZIRIK, Nelson. Administração de cartão de crédito constitui atividade privativa de instituição financeira? Revista de Direito Mercantil, Industrial, Econômico e Financeiro. São Paulo: RT, 1992, n. $88,30 \mathrm{p}$.
} 


\section{Limitação das Taxas das Plataformas de Pagamentos}

A principal consequência do entendimento demonstrado acima, qual seja, de que as atividades das Plataformas de Pagamentos não devem ser consideradas como privativas de instituições financeiras, uma vez lhes faltarem diversos pressupostos que poderiam configurá-las como tal, é a limitação das Taxas que poderão cobrar para a prestação de seus serviços.

Em razão disso, se faz necessária a análise das Taxas cobradas pelas Plataformas de Pagamentos e a sua eventual limitação pelo Decreto $\mathrm{n}^{\circ} 22.626$, de 7 de abril de 1933, conforme alterado ("Lei da Usura"), ou pela Lei $n^{\circ}$ 10.406, de 10 de janeiro de 2002, conforme alterada ("Código Civil Brasileiro" $)^{17}$. Ressaltamos que, segundo entendimento do Supremo Tribunal Federal, a Lei da Usura não se aplica às instituições financeiras, públicas ou privadas, quanto às taxas de juros e aos outros encargos cobrados nas operações realizadas no âmbito do Sistema Financeiro Nacional ${ }^{18}$.

A Lei da Usura, em seu artigo $1^{\circ}$, dispõe que:

"Art. 1". É vedado, e será punido nos termos desta lei, estipular em quaisquer contratos taxas de juros superiores ao dobro da taxa legal"

À época da Lei da Usura, a taxa legal era aquela prevista no artigo 1.063 do antigo Código Civil de $1916^{19}$, que dispunha que os juros legais estariam

\footnotetext{
${ }^{17}$ Tal discussão sobre a aplicabilidade da Lei da Usura ou do Código Civil Brasileiro é motivo de ampla divergência doutrinária e jurisprudencial (Resp 910.799/RS e Resp 727.842/SP).

${ }^{18}$ STF Súmula $\mathrm{n}^{\circ} 596$ - Juros nos Contratos - Aplicabilidade em Taxas e Outros Encargos em Operações por Instituições Públicas ou Privadas que Integram o Sistema Financeiro Nacional: "As disposições do Decreto 22.626 de 1933 não se aplicam às taxas de juros e aos outros encargos cobrados nas operações realizadas por instituições públicas ou privadas, que integram o sistema financeiro nacional."

19 “Art. 1.063. Serão também de seis por cento ao ano os juros devidos por força de lei, ou quando as partes os convencionarem sem taxa estipulada."
} 
limitados a $6 \%$ ao ano. Por isso, a Lei da Usura limita a cobrança de juros ao dobro da taxa legal, isto é, no valor de $12 \%$ ao ano.

Por outro lado, o novo Código Civil Brasileiro veio a dispor, em seu artigo 591, que “destinando-se o mútuo a fins econômicos, presumem-se devidos juros, os quais, sob pena de redução, não poderão exceder a taxa a que se refere o art. 406”. Assim, o artigo 406 do Código Civil Brasileiro se refere à taxa "que estiver em vigor para a mora do pagamento de impostos devidos à Fazenda Nacional", isto é, a taxa referencial do Sistema Especial de Liquidação e Custódia - SELIC.

Considerando que ambas as limitações, seja pela Lei da Usura ou pelo Código Civil Brasileiro, afetariam o modo pelo qual as Plataformas de Pagamentos tarifam seus serviços, a questão central deste item se resume em determinar se as Taxas cobradas por elas, isto é, a "antecipação de pagamento" ou o "desconto mercantil", se enquadram na definição legal de juros, e, portanto, se deveriam sofrer algum tipo de limitação.

Inicialmente, pode-se dizer que parte da remuneração recebida pelas Plataformas de Pagamentos decorre da antecipação dos valores que o Vendedor faria jus em razão de suas vendas, mediante um "desconto mercantil", isto é, uma antecipação a menor, com deságio ou redução de valor.

Tal desconto, materializado por meio da cobrança das Taxas, varia de acordo com a data do pagamento agendado e o custo do dinheiro no tempo.

Os juros constituem o preço pelo uso do capital, isto é, a expressão econômica da utilização do dinheiro. Pode-se dizer que os juros possuem tanto o escopo de promover a remuneração do credor pela privação de seu capital quanto compensar-lhe pelo risco de sua não restituição ${ }^{20}$. Ou seja, do ponto de

\footnotetext{
${ }^{20}$ TEPEDINO, Gustavo, et. al. Código Civil Interpretado. Rio de Janeiro: Editora Renovar, $2^{\circ}$ edição, vol. 2, $406 \mathrm{p}$.
} 
vista jurídico, os juros seriam “a contrapartida que alguém paga por temporária utilização de capital alheio" ${ }^{21}$.

Diante desses conceitos, a jurisprudência vem se manifestando no sentido de que, sendo os juros o "preço do capital", taxas de desconto, tais como as efetuadas pelas Plataformas de Pagamentos, em certos casos, corresponderiam aos juros a partir da data em que o capital é disponibilizado até o momento em que ocorre o efetivo recebimento dos recursos.

\author{
Assim entendeu o E. Superior Tribunal de Justiça ${ }^{22}$ :
}

"Assim, sendo os juros o "preço do dinheiro", servindo como compensação, ou indenização à parte que disponibiliza o capital à outra, por tempo determinado, nãao há outra conclusão a ser tirada do presente caso senão a de que a "taxa de desconto" cobrada pela recorrente corresponde aos juros incidentes sobre o capital que empresta (adiantamento) a partir da data em que é disponibilizado até o momento em que ocorre a efetiva quitação do mútuo - compensação entre o valor que foi emprestado e aquele que a empresa que tomou o empréstimo (pediu o adiantamento) tem para receber da mutuante.

Portanto, a "taxa de desconto", cobrada nas operações de antecipação de pagamento dos valores das transações realizadas com cartões de crédito, corresponde a juros compensatórios, não havendo como ser afastada a limitação em $1 \%$ ao mês imposta nas instâncias ordinária."

(grifos e negritos nossos)

Entendeu assim, também, o Tribunal de Justiça do Rio Grande do $\mathrm{Sul}^{23}$, no âmbito do voto que deu origem ao mencionado Recurso Especial ao E. Superior Tribunal de Justiça:

"Por esse motivo, a empresa ré está limitada pela Lei de Usura (Decreto $n^{o}$ 22.626/33) e não pode praticar operação bancária de desconto mercantil com deságio ou taxa superior ao limite legal da taxa de juros, que fica sendo de $12 \%$ ao

\footnotetext{
${ }^{21}$ COSTA, JUDITH MARTINS. Comentários ao Novo Código Civil. Rio de Janeiro: Editora Forense, 2009, $2^{\circ}$ edição, 569 p.

${ }^{22}$ REsp n ${ }^{\circ} 10.799 /$ RS, de relatoria do Ilmo. Ministro Sidnei Beneti, no qual o E. Superior Tribunal de Justiça julgou procedente a limitação da remuneração relativa à antecipação de pagamento de uma credenciadora de cartão de crédito (a qual não era instituição financeira) em $1 \%$ ao mês, nos casos dos estabelecimentos que desejassem receber determinada quantia antes do prazo.

${ }^{23}$ Apelação cível $n^{\circ} 70009285248$, Comarca de Porto Alegre, de relatoria do Ilmo Desembargador Ney Wiedemann.
} 
ano, pelo disposto nos artigos 1.062 e 1.262 do Código Civil de 1916 e pelo art. $1^{o}$ do Decreto $n^{o}$ 22.626/33, cumulável com a correção monetária pelo IGPM, indexador que se aplica por melhor medir a inflação, ausente outro expressamente pactuado pelos contratantes."

Não obstante os julgados acima se resumirem à relação entre o estabelecimento comercial e a credenciadora do cartão de crédito, é perceptível que a antecipação que tais sociedades realizam em determinados casos mantém absoluta identidade ao que é realizado pelas Plataformas de Pagamentos.

Nesse sentido se manifestou mais uma vez aquele Tribunal de Justiça de Rio Grande do Sul, também no âmbito do voto que deu origem ao mencionado Recurso Especial ao E. Superior Tribunal de Justiça:

"Nessa linha de entendimento, vedado está à administradora cobrar desconto mercantil pelo pagamento antecipado das vendas em percentual superior ao limite legal dos juros, da ordem de $12 \%$ ao ano, cumulados com correção monetária pelo IGPM.

Isso porque já está sendo remunerada pelo serviço que presta, na razão de 3\% sobre o produto das vendas feitas pelo estabelecimento conveniado, ou seja, o comerciante."

(grifos e negritos nossos)

Isto posto, é necessário atentar para o fato de que, além de não serem regulamentadas pelo Bacen, a principal consequência da não caracterização das Plataformas de Pagamento como Instituição Financeira é o fato de que as Taxas cobradas pelas Plataformas de Pagamento têm que obedecer o disposto na Lei de Usura e suas limitações. Caso não observem as limitações, poderão acontecer questionamentos em juízo e as Plataformas de Pagamentos serão compelidas a reembolsar o autor da ação o montante que exceder o valor imputado como taxa legal pelo Código Civil Brasileiro. 


\section{Outros Aspectos Jurídicos Relevantes}

\subsection{O Chargeback}

Conceitualmente, o Chargeback é o procedimento operacional por meio do qual determinado comprador contesta um débito, por ele não reconhecido, relativo a uma despesa efetuada com o cartão de sua titularidade, com o fim de invalidar tal pagamento junto à sua administradora de cartões ou ao banco emissor do cartão de crédito.

Em sentido mais amplo entendeu Waldo Fazzio Júnior ${ }^{24}$, ao conceituar o Chargeback como sendo o procedimento operacional por meio do qual a emissora / administradora de cartão de crédito, ou o titular do cartão, impugna determinada transação acarretando no cancelamento do repasse ou estorno do crédito, se já efetuado, por parte da credenciadora.

Tal recusa por parte do comprador pode se dar em razão de diversas hipóteses, tais como (i) a utilização indevida de cartão de crédito por terceiro em razão de furto, clonagem ou roubo; e/ou (ii) o inadimplemento contratual por parte do vendedor, seja pela não entrega do bem ou pela não prestação do serviço contratado. Já com relação à emissora / administradora de cartão de crédito, o Chargeback pode ocorrer em razão da inobservância dos procedimentos previstos nos contratos celebrados entre esta e o comprador.

Em uma relação contratual entre o comprador e o vendedor na qual figura, ainda, uma Plataforma de Pagamentos, esta é a responsável pelo repasse dos recursos oriundos do comprador e a ela entregues pelo Credenciador, o que a qualifica como responsável, para todos os fins, pela guarda dos valores enquanto não os repassa ao vendedor.

\footnotetext{
${ }^{24}$ JÚNIOR, WALDO FAZZIO. Cartão de crédito, cheque e direito do consumidor. São Paulo: Editora Altas, 2011, $252 \mathrm{p}$.
} 
Nas operações onde figuram tais entidades, o crédito remetido pelo Credenciador é depositado diretamente em conta de titularidade da Plataforma de Pagamentos, podendo-se dizer que o Credenciador (i.e., a entidade que repassaria os recursos originariamente ao vendedor caso não houvesse a Plataforma de Pagamentos) relaciona-se, única e exclusivamente, com a Plataforma de Pagamentos, não havendo qualquer relação de reciprocidade entre aquele e o vendedor.

Diante disso, e no que tange à Plataforma de Pagamentos, entende-se que na ocorrência de um Chargeback, a única responsável por restituir ao Credenciador os recursos oriundos da venda realizada pelo Vendedor seria a própria, na qualidade de sujeito passivo direto da relação contratual estabelecida com o Credenciador.

\subsection{A utilização fraudulenta de cartão de crédito}

Não obstante o exposto, cumpre analisar a hipótese específica de utilização indevida de cartão de crédito por terceiro, em razão de furto, roubo ou clonagem de cartão e a obrigatoriedade de estorno dos recursos recebidos pela Plataforma de Pagamentos ao Credenciador.

Nesse caso, a obrigação da devolução dos recursos pela Plataforma de Pagamentos não é tão evidente. Ao revés, a doutrina brasileira vem entendendo pela única e exclusiva responsabilidade das administradoras de cartões em casos, por exemplo, de cartão de crédito clonado.

Entende ainda a doutrina pela não responsabilização do estabelecimento de venda em caso da utilização de cartão clonado por terceiro. Como se sabe, os cartões de crédito são oferecidos ao público por intermédio da administradora ou banco administrador, que, como emitente do veículo de pagamento utilizado perante o estabelecimento credenciado, se responsabiliza pela apresentação do cartão clonado. Portanto, a venda somente deveria se 
concretizar após a prévia consulta de higidez do cartão exibido perante a administradora, pois, não havendo tal consulta, não poderia se afirmar a autenticidade do portador ou do próprio cartão.

Fortalecendo o que a doutrina vem entendendo, o Tribunal de Justiça do Estado de São Paulo já se manifestou no sentido de que o lojista (e, alargando tal conceito nas atividades de compra e venda na internet, a Plataforma de Pagamentos) não seria responsável por restituir os créditos advindos de uma operação fraudulenta. A clonagem de cartão de crédito, nesse entendimento, estaria inserida no rol dos riscos advindos da exploração dos serviços oferecidos pela própria administradora de cartão de crédito, a qual seria, portanto, a única responsável pela robustez e segurança desse meio de pagamento.

Com efeito, o voto do Ilmo. Desembargador Relator, no âmbito da Apelação $\mathrm{n}^{\circ}$ 9121827-44.2008.8.26.0000, em trâmite perante a $25^{\circ}$ Câmara Cível do Tribunal do Estado de São Paulo, que ilustra a situação acima:

"Ademais, a fraude de cartões de crédito, dentre outras irregularidades ligadas ao sistema é problema a ser resolvido pelas administradoras de cartões de crédito, pois se insere na sua atividade de risco e não na atividade do comerciante, de modo que deve responder pelos prejuízos causados a terceiros. Vale dizer, o risco é da administradora, que o assumiu no momento em que se propôs a fornecer o serviço." (grifos nossos)

Ainda, cumpre citar dois julgados em mesmo sentido, in verbis:

\begin{abstract}
"Prestação de serviços - Indenização - Cartão de crédito - Clonagem - Operação autorizada pela administradora do cartão - Inexistência de responsabilidade do lojista - Indenização por danos materiais - Cabimento Dever da administradora de fiscalizar e prover meios que Impeça a falsificação dos cartões de crédito. A clonagem de cartão de crédito insere-se dentre os riscos da exploração dos serviços pela administradora, que deve por eles se responsabilizar, sendo descabida a atribuição do débito ao lojista afiliado. ${ }^{25, "}$
\end{abstract}

${ }^{25}$ Apelação n ${ }^{\circ}$ 1.155.678-0/0 26 Câmara Cível do Tribunal do Estado de São Paulo. Ilmo. Des. ANDREATTA RIZZO. 14.04.2008. 
"Responsabilidade civil - Cartão de crédito - Operação efetuada após obtenção de autorização eletrônica da administradora Superveniente estorno da transferência do valor correspondente sob a alegação de que portador do cartão não reconheceram o débito - Improcedência Notícia de subtração do cartão inexistente - Divergência de assinaturas não imputável ao lojista filiado - Possibilidade de clonagem do cartão pelo comprador para utilização na aquisição de produtos - Inobservância da administradora do dever de fiscalizar e prover meios que impeçam falsificação ou duplicação dos cartões de crédito - Assunção do risco do negócio - Cobrança procedente - Apelo improvido. ${ }^{26 "}$

Como demonstrado acima, há uma certa tendência jurisprudencial em entender que não há obrigação legal, para os estabelecimentos de venda e, por analogia, às Plataformas de Pagamentos, de restituição dos valores em casos de fraude de cartão de crédito pelos estabelecimentos de venda.

\subsection{O Direito de Regresso}

Com relação ao direito de regresso, e em caso de estorno pela Plataforma de Pagamentos dos recursos ao Credenciador $^{27}$ em razão do Chargeback, restaria àquela apenas o direito de regresso junto ao Vendedor, uma vez que este é considerado, por sua vez e para todos os fins, o sujeito passivo direto da relação perante o Adquirente, bem como a pessoa que incorreria em todos os riscos do negócio caso a relação estivesse sido realizada sem a sua interveniência.

O direito de regresso está previsto no artigo 934 do Código Civil, o qual dispõe que "aquele que ressarcir o dano causado por outrem pode reaver o que houver pago daquele por quem pagou, salvo se o causador do dano for descendente seu, absoluta ou relativamente incapaz".

Duas maneiras são comumente utilizadas pelas Plataformas de Pagamentos para materializar o direito de regresso e recompor o débito criado

\footnotetext{
${ }^{26}$ Apelação n ${ }^{\circ}$ 7.175.323-8 $19^{\circ}$ Câmara Cível do Tribunal do Estado de São Paulo. Ilmo. Des. RICARDO NEGRÃO. 27.11.07.

27 Notem que, neste caso, desconsideramos o eventual questionamento judicial do Vendedor pelos valores resgatados de sua conta nos casos de Chargeback por fraude do cartão de crédito, conforme abordado no item 6.2 .
} 
com o Chargeback, quais sejam: (i) débito direto na conta do vendedor vinculada à Plataforma de Pagamentos, quando houver débitos suficientes em conta para cobrir pretendido reembolso junto ao Credenciador; ou (ii) na hipótese de não haver saldo suficiente para cobrir o valor em questão, as Plataformas de Pagamentos podem prever contratualmente a obrigação de ressarcimento por parte do vendedor por quaisquer meios admitidos em direito. Há, ainda, outra medida adotável pela Plataforma de Pagamentos na tentativa de limitar os riscos de inadimplemento do vendedor: a retenção dos recursos disponíveis na conta deste caso uma disputa de Chargeback esteja em curso, o que mitigaria eventuais saques que visem a não recomposição do débito pelo vendedor.

Cita-se, a título ilustrativo, o caso da PayPal do Brasil Serviços de Pagamentos Ltda., que dispôs em seu "Contrato do Usuário”, nas Cláusulas 3.1 e $6.2^{28}$, o quanto segue:

"3.1 Responsabilidade por pagamentos invalidados. Ao receber um pagamento, você é responsável perante o PayPal pelo valor integral desse pagamento, mais eventuais Tarifas, caso tal pagamento seja posteriormente invalidado por alguma razão. Isso significa que, caso você perca uma Reclamação ou um Chargeback ou caso o pagamento enviado a você seja Cancelado, além de quaisquer outras obrigações, você responderá pelo valor do pagamento que lhe foi enviado, mais as Tarifas aplicáveis listadas no Anexo A deste Contrato (Tarifas). Você concorda em ressarcir o PayPal de quaisquer valores devidos por meio de débito em sua Conta.

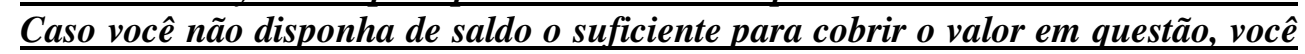
deverá pagar o PayPal por outros meios. Caso o remetente de um pagamento peça Chargeback, o emissor do cartão de crédito, e não o PayPal, é o responsável por determinar se o Chargeback deve ser completado."

6.2 Limitações sobre o encerramento de sua conta. Você não poderá impedir eventual investigação encerrando sua conta. Caso você venha a encerrar sua conta enquanto estivermos conduzindo uma investigação, nós poderemos reter seus recursos para proteger o PayPal, sua controladora, suas subsidiárias e coligadas ou terceiros do risco de cancelamentos, chargebacks, reclamações, tarifas, multas,

\footnotetext{
${ }^{28}$ Não há como afirmar, todavia, que as mencionadas disposições contratuais, constantes de um contrato de adesão, não seriam afastadas em juízo por considerá-las abusivas sob a ótica do consumidor.
} 
penalidades e outras obrigações. Você continuará responsável por todas as obrigações relacionadas a sua conta, mesmo após seu o encerramento."

(grifos e negritos nossos)

Da mesma maneira dispõe o "Contrato de Prestação de Serviços de Gestão de Pagamentos e Outras Avenças”, no caso da Universo Online S.A, em suas Cláusulas 53 e 54:

\begin{abstract}
"53. No caso de ser o PAGSEGURO obrigada a efetuar qualquer tipo de estorno no Registro de Serviço do CONTRATANTE, ou para a Fonte de Recursos, o CONTRATANTE estará obrigado ao pagamento, em favor do PAGSEGURO, das taxas de estorno e dos custos e despesas previstos na tabela de preços mencionada na cláusula "52".

54. Os valores devidos ao PAGSEGURO serão pagos através da dedução, no Registro de Serviço do CONTRATANTE, dos créditos correspondentes ao valor devido pela utilização do Serviço. A dedução dos créditos referentes aos valores devidos ao PAGSEGURO será feita quando da dedução dos créditos referentes ao Pagamento ou à Movimentação que lhes deu causa ou quando da ocorrência de qualquer outro evento que exija o pagamento por parte do CONTRATANTE. Caso, por qualquer motivo, não disponha de créditos suficientes em seu Registro de Serviço, o CONTRATANTE pagará imediatamente ao PAGSEGURO os valores devidos por meio de boleto bancário."
\end{abstract}

\title{
6.4. A Hipótese da Responsabilidade Solidária do Vendedor e da Plataforma de Pagamentos
}

Como exposto acima, a relação contratual de compra e venda entre o Vendedor e o Adquirente conta com a interveniência da Plataforma de Pagamentos, como forma de dar segurança e agilidade aos comitentes e a mesma, na qualidade de mera repassadora de recursos.

Sob a ótica de uma relação contratual simplificada, pode-se dizer que a Plataforma de Pagamentos não figuraria no polo passivo (i.e., como devedora) em uma disputa judicial no caso de inadimplemento contratual por parte do Vendedor, uma vez que a relação se dá, primordialmente, entre o Adquirente e o Vendedor, recaindo sobre a Plataforma de Pagamentos apenas a obrigação de 
entregar, tempestivamente, os recursos ao Vendedor e intermediar qualquer conflito porventura iniciado entre as partes.

Por outro lado, parte da doutrina brasileira vem se filiando à tese de que esse tipo de relação contratual possui caráter complexo, isto é, uma relação dotada de um encadeamento de eventos interligados. Observando-se a relação sob essa ótica, a Plataforma de Pagamentos poderia ser chamada a responder em conjunto (i.e., solidariamente ${ }^{29}$ ) com o Vendedor e todos os outros agentes da relação em caso de disputa judicial, inclusive o Credenciador e a administradora do cartão de crédito. Isto se dá pois presumir-se-ia, em certas ocasiões, que a Plataforma de Pagamentos, o Vendedor e os agentes responsáveis pelo crédito do consumidor estariam inseridos em uma cadeia complexa de prestação de serviços (i.e., uma cadeia de fornecimento), onde o consumidor não tem condições de identificar de maneira lógica a responsabilidade atribuída a cada um individualmente ${ }^{30}$.

Ademais, no âmbito de uma relação contratual complexa de compra e venda, se mostra relevante conceituar a pessoa do fornecedor, bem como a cadeia de fornecimento, na visão do Direito do Consumidor.

Segundo o artigo $3^{\circ}$ da Lei $\mathrm{n}^{\circ} 8.078$, de 11 de setembro de 1990, conforme alterada ("CDC"), o fornecedor "é toda pessoa física ou jurídica, pública ou privada, nacional ou estrangeira, bem como os entes despersonalizados, que desenvolvem atividade de produção, montagem, criação, construção, transformação, importação, exportação, distribuição ou comercialização de produtos ou prestação de serviços" $" 31$.

\footnotetext{
${ }^{29}$ Conceitua-se solidariedade passiva como "aquela que obriga todos os devedores ao pagamento total da dívida. Sua importância é enorme na vida negocial porque, como já acenado, se trata de meio muito eficiente de garantia, de reforço de vínculo, facilitando o adimplemento". (VENOSA, Sílvio de Salvo. Direito Civil. $8^{\circ}$ ed., vol. 2. São Paulo, 2008. 109 p.)

${ }_{30}$ Pela novidade das facilitadoras de pagamento nas relações de compra e venda no e-commerce brasileiro, não há como afirmar que o entendimento em questão seria utilizado para defini-las como parte integrante da cadeia de fornecimento.

${ }^{31}$ Como bem ressalta Antônio Carlos Efing, o rol de hipóteses previstas no CDC que enquadram o conceito de fornecedor não é exaustivo. (EFING, Antônio Carlos. Contratos e Procedimentos Bancários à luz do Código de Defesa do Consumidor. São Paulo. Revista dos Tribunais, 2012. 134 p.).
} 
Com isso, e a partir da análise do dispositivo legal mencionado, a cadeia de fornecimento pode ser entendida como um fenômeno econômico de organização do modo de produção e distribuição e de fornecimento de serviços complexos, envolvendo grande número de atores que unem esforços e atividades para uma finalidade comum, qual seja, a de poder oferecer no mercado produtos e serviços para os consumidores ${ }^{32}$.

Com efeito, os sujeitos participantes dessa cadeia estariam conectados pelo fim comum, isto é, a produção / distribuição de bens e serviços ao titular do cartão de crédito, sendo considerados para todos os fins, pois, solidários.

Entende-se que participam da cadeia de fornecimento os fornecedores diretos ou indiretos, não importando, pois, se a relação com o consumidor foi dada de maneira direta, indireta, contratual ou extracontratual.

Por isso, em caso de dano causado ao consumidor, seja ele próprio ou equiparado, este poderá acionar, em algumas situações, qualquer um dos agentes ou até mesmo toda a cadeia de fornecimento, os quais responderão solidariamente pela reparação dos danos previstos, conforme dispõe o artigo $7^{\circ}$, parágrafo único, do $\mathrm{CDC}^{33}$.

Nesse sentido foi o voto da Ilma. Desembargadora Relatora da $15^{\circ}$ Câmara Cível do Tribunal do Estado do Rio de Janeiro, no âmbito do Processo $\mathrm{n}^{\circ}$ 0005711-61.2012.8.19.0001, in verbis:

\footnotetext{
"No sistema da lei consumerista, como cediço, a responsabilidade do fornecedor pela reparação de danos causados ao consumidor decorrentes de defeitos relativos à prestação dos serviços é objetiva, sendo necessários somente a comprovação do evento danoso, da conduta do agente e do nexo entre o ato praticado e o dano sofrido.
}

Estabelece o referido diploma legal, ademais, a responsabilidade solidária dos fornecedores de produtos e serviços "na medida em que montaram uma verdadeira cadeia de prestação de serviços sem que o consumidor tenha condições de identificar

\footnotetext{
32 MARQUES, Cláudia Lima. Contratos no Código de Defesa do Consumidor: o novo regime das relações contratuais. São Paulo: Revista dos Tribunais, 2005.

33 “Art. $7^{\circ}$ (...) Parágrafo único. Tendo mais de um autor a ofensa, todos responderão solidariamente pela reparação dos danos previstos nas normas de consumo."
} 
qual seja a responsabilidade de cada qual", como bem consignou o douto sentenciante em seu decisum.

Nesse passo, a alegacão da apelante de que seria mera gestora de pagamentos não afasta a sua responsabilidade e não a exonera de garantir a entrega do produto, ainda que não seja propriamente a vendedora, pois além de auferir lucros pela intermediação, participa da relação jurídica de compra e venda dentro da cadeia de consumo da qual os autores são os destinatários finais.

Não pode a apelante simplesmente impor aos autores, parte mais fraca na relação de consumo, o dever de utilizar o procedimento para solicitação do estorno, que denomina "disputa" para evitar a concretização o do negócio. Inviável a sua pretensão que não encontra respaldo diante do ordenamento jurídico protetivo da parte consumidora."

(grifos e negritos nossos)

É possível destacar, ainda, entendimento da Ilma. Desembargadora Relatora da $5^{\circ}$ Câmara Cível do Tribunal de Justiça do Rio de Janeiro, no âmbito da apelação cível $\mathrm{n}^{\circ}$ 2008.001.47906, o qual explicita a solidariedade de todos os agentes em uma cadeia de fornecimento em complexas operações de compra e venda, senão vejamos:

"Para a Consumidora, as Rés se apresentaram como unidade na operação complexa de compra e venda. Neste diapasão, para a aferição da responsabilidade, saber se $O$ erro partiu da operadora de cartões de crédito, da loja da qual adquiriu os produtos não é relevante, tendo em vista o que determinam os artigos $7^{\circ}$, parágrafo único e 14 todos do CDC.

Ressalto que, sendo a segunda Ré credenciada da Operadora, torna-se responsável solidária na cadeia de consumo, nos termos do parágrafo único, do parágrafo único do art. $7^{\circ}$ do Código de Defesa do Consumidor que diz assim: "todos os participes do ciclo produtivo respondem solidariamente pela reparação dos danos previstos nas normas de consumo."

(grifos nossos)

Finalmente, o entendimento emitido pelo E. Superior Tribunal de Justiça, reconhecido no voto da Ilma. Ministra-Relatora Nancy Andrighi, proferido no âmbito do Recurso Especial 1.029.454/RJ: 
"Na hipótese concreta, há uma verdadeira cadeia de fornecimento de serviços. Há clara colaboração entre a instituição financeira, a administradora do cartão de crédito e a bandeira "Visa", que fornecem serviços conjuntamente e de forma coordenada.

Independente de manter relação contratual com o autor, não administrar cartões de crédito e não proceder ao bloqueio do cartão, as 'bandeiras', de que são exemplos Visa, Mastercard e American Express, concedem o uso de sua marca para a efetivação de serviços, em razão da credibilidade no mercado em que atuam, o que atrai consumidores e gera lucro.

Por onde quer que se veja a questão, deve-se concluir que há estreita cooperação entre a instituição financeira, a administradora do cartão de crédito e a 'bandeira', pois só assim a prestação do serviço se torna viável. $O$ art. 14 do CDC estabelece verdadeira regra de responsabilidade solidária entre os fornecedores de uma mesma cadeia de serviços e por esta razão que as 'bandeiras' de cartão de crédito respondem pelos danos decorrentes da má prestação do serviço.

A solução é, por outro lado, absolutamente consentânea com as premissas adotadas pelo CDC para a matéria. Privilegia-se o acesso da vítima à reparação do dano, com o reconhecimento da solidariedade entre os agentes que compõem a cadeia de fornecimento de serviços." ${ }^{34}$ (grifos nossos)

Dessa forma, levando em consideração o tratamento do E. Superior Tribunal de Justiça em relação às "bandeiras", não há como afastar a possibilidade de que o mesmo seja dado às facilitadoras de pagamento.

Tal posicionamento, todavia, não qualifica exclusivamente a Plataforma de Pagamentos como única parte responsável (i) pelo ressarcimento do Comprador, sobretudo se por culpa exclusiva do Vendedor; ou (ii) pelo ressarcimento da totalidade do valor referente ao dano sofrido pelo Comprador. Isto porque o arcabouço legal brasileiro prevê um instituto cujo objetivo é tentar recompor a reciprocidade ora quebrada por força da solidariedade passiva decorrente do CDC: o Direito de Regresso (consoante item 6.3 deste memorando).

Da mesma forma, inclusive, se manifestou a Ministra-Relatora Nancy Andrighi, no âmbito do voto imediatamente supramencionado, senão vejamos:

\footnotetext{
${ }^{34}$ No mesmo sentido, ainda podemos fazer referência ao voto também proferido Ilma. Ministra Nancy Andrighi, no âmbito do Recurso Especial 1.058.221/PR.
} 
"A solução é, por outro lado, absolutamente consentânea com as premissas adotadas pelo CDC para a matéria. Privilegia-se o acesso da vítima à reparação do dano, com o reconhecimento da solidariedade entre os agentes que compõem a cadeia de fornecimento de serviços.

Ressalte-se que os limites da responsabilidade contratual existentes entre os fornecedores do serviço.

Com efeito, poderá a recorrente, se for o caso, resguardar direito regressivo perante os demais integrantes da cadeia de fornecedores." (grifos e negritos nossos)

Como forma de materializar esse direito de regresso, entende-se que, nos casos onde os membros da cadeia de fornecimento são chamados em juízo para responder de maneira solidária, o direito de regresso poderia ser invocado por aquele que venha a indenizar, no todo ou em parte (conforme aplicável), os prejuízos sofridos pelo consumidor, observada a sua parcela de culpa no dano causado.

Pode-se dizer que caso o fornecedor que tenha ressarcido o consumidor venha a provar que não deu qualquer causa ao dano, aquele terá direito ao regresso integral dos valores e/ou bens entregues. Em outras palavras, e nos atendo à análise da Plataforma de Pagamentos, caso a ela venha a ressarcir o Adquirente por fato que tenha sido causado única e exclusivamente pelo Vendedor, a mesma poderá pleitear em juízo o ressarcimento integral do que fora anteriormente desembolsado.

Nesse sentido entendeu o E. Superior Tribunal de Justiça por meio do voto do Ilmo. Ministro-Relator Paulo de Tarso Sanseverino, proferido no âmbito do Recurso Especial 1.165.279/SP, a saber:

"O eminente Ministro Herman Benjamin, analisando a questão em sede doutrinária, anota que o direito de regresso é uma conseqüência natural da solidariedade legal estabelecida no CDC, observando que a localização da norma foi “infeliz", pois o instituto abrange também as demais hipóteses de responsabilidade por acidentes de consumo, que estão previstas nos artigos 12 e 14 do CDC (BENJAMIN, Antônio 
Herman de Vasconcelos. Comentários ao código de proteção do consumidor. São Paulo: Saraiva, 1991, p. 76).

$(\ldots)$

Cláudia Lima Marques lembra, corretamente, que, nas relações internas entre os fornecedores, no curso da ação de regresso, a natureza da responsabilidade passa a ser estritamente subjetiva nos moldes do sistema tradicional. Quando o parágrafo único do art. 13 do CDC diz "segundo sua participação na causação do evento", passa-se a discutir a possibilidade de imputação subjetiva do defeito ao fornecedor demandado. E complementa com o exemplo de defeito na fabricação de iogurte: "O comerciante pode até ser responsabilizado pelos danos causados à saúde de seus clientes e de suas famílias, pois está mais próximo e se presume que tenha falhado na conservação do produto perecível, mas, se o defeito do produto foi causado pelo fabricante, terá o comerciante direito de regresso e, se o defeito que deu origem ao evento danoso foi causado totalmente pelo fabricante, terá direito ao regresso integral" (MARQUES, Cláudia Lima. Contratos no Código de Defesa do Consumidor . 3. ed. São Paulo: Revista dos Tribunais, 1999, p. 630)."

(grifos e negritos nossos)

Diante de todo o exposto, é sempre necessário considerar o entendimento - muitas vezes pró-consumerista - adotado por nossos tribunais (como nos processos citados acima ${ }^{35}$ ), inclusive os superiores, bem como por boa parte da doutrina, de que as Plataformas de Pagamentos fazem parte de uma cadeia de fornecimento e, portanto, respondem solidariamente em caso de disputa judicial envolvendo a relação de consumo. Nesses casos, jurisprudência também é pacífica no tocante ao exercício do direito de regresso nas situações em que o dano tiver sido causado por outros integrantes da cadeia de fornecimento, tal como o Vendedor.

\footnotetext{
35 Não encontramos, além do Processo $n^{\circ}$ 0005711-61.2012.8.19.0001, precedentes adicionais que envolvam Plataformas de Pagamentos nos tribunais superiores dos Estados do Rio de Janeiro e São Paulo, motivo pelo qual conclui-se que o tema não foi enfrentado de maneira consistente em juízo.
} 


\section{Conclusão}

Por todo o exposto acima, pode-se concluir que as Plataformas de Pagamentos não podem ser consideradas Instituições Financeiras e, portanto, neste momento, não fazem parte Sistema Financeiro Nacional e nem são reguladas, pelo CMN ou Bacen. Isso porque, apesar de fazerem o repasse dos recursos de terceiros, suas atividades não são semelhantes àquelas das instituições financeiras, conforme visto no Capítulo 4 acima, quais sejam, (i) coleta e aplicação de recursos de terceiros; (ii) operação de mútuo; (iii) interposição profissional; e (iv) intermediação especulativa.

Como consequência deste entendimento, conclui-se que as Plataformas de Pagamentos estão sujeitas às limitações da Lei de Usura, uma vez que apenas as instituições financeiras são as únicas excetuadas das referidas limitações.

Para o encerramento do debate sobre o papel e regulamentação destas sociedades cada vez mais presentes no dia-a-dia da população brasileira, faz-se necessária uma manifestação do $\mathrm{CMN}$ ou do Bacen quanto ao papel destas instituições no Sistema Financeiro Nacional.

A regulamentação, realmente, é importante, pois as Plataformas de Pagamentos são engrenagens vitais ao setor de E-commerce, o qual se desenvolve mundialmente de forma assustadora: estudos restritos ao Brasil indicam que, em 12 anos (i) o acesso da população brasileira a cresceu de 12 milhões para 90 milhões de usuários ( $45 \%$ da população brasileira), um salto de 650\%; (ii) o número de consumidores online cresceu em $3.536 \%$ e chegando ao incrível número de 40 milhões; e (iii) o E-Commerce gerou um faturamento de $\$ 22,5$ bilhões $^{36}$. Estes dados reiteram a intensidade com a qual o brasileiro abraçou o E-commerce e o crescimento intenso do setor.

\footnotetext{
${ }^{36}$ Informação retirada do http://www.e-commerce.org.br/. Acesso em 7 de novembro de 2013.
} 
É preciso dar a devida atenção e regular as instituições que fazem parte deste setor. A Europa, por exemplo, fez questão de regular, em 18 de setembro de 2000 (há 13 anos!), o que eles chamam de "Eletronic Money Institution".

Segundo a Diretiva 2000/46/EC do Parlamento Europeu e do Conselho da União Europeia (Directive 2000/46/EC of the European Parliament and of the Council of the European Union) (Anexo III), "it is necessary to take account of the specific characteristic of these institutions and to provide the appropriate measures necessary to coordinate and harmonise laws regulations and administrative provisions relating to the taking up, pursuit and prudential supervision of the business of electronic money institutions".

Não obstante o fato de que as electronic money institutions não guardarem semelhanças com as Plataformas de Pagamentos, chama atenção o fato de que a União Europeia emitiu uma diretiva específica para essas instituições e demonstra um cuidado específico com o E-commerce, enquanto nossas entidades do subsistema normativo do Sistema Financeiro Nacional permanecem silenciosas sobre o tema.

Tamanha é a importância do E-commerce e, por consequência, das instituições que fazem parte dele, que, na justificativa da referida diretriz europeia, a entidade responsável afirma que "the issuance of electronic money may affect the stability of the financial system and the smooth operation of payment systems".

Tal regulação sem dúvida garantiria uma maior segurança aos consumidores online e às lojas virtuais, uma vez que a atuação dessas instituições e forma de repasse dos recursos das transações passaria a ser realizada em seus termos, gerando inclusive um aumento ainda maior do setor do E-commerce no Brasil.

Uma regulação específica para as Plataformas de Pagamentos, que trabalham exclusivamente com esta "moeda eletrônica" se mostra, portanto, imprescindível. Pelo entendimento aqui expresso, tal regulação não seria a 
mesma de uma instituição financeira, visto que as Plataformas de Pagamentos não realizam suas funções. Mas isto não impede que o CMN e o Bacen emitam resoluções que regulem as atividades das Plataformas de Pagamentos, sua constituição, funcionamento, juros a serem cobrados, etc. 


\section{Bibliografia}

\section{Doutrina}

FORTUNA, Eduardo. Mercado Financeiro: produtos e serviços. $17^{\mathrm{a}}$ Ed., Rio de Janeiro: Qualitymark, 2008.

CARVALHO, Fernando J. Cardim de et al.. Economia Monetária $e$ Financeira. $3^{\circ}$ Ed., Rio de Janeiro: Editora Campus, 2001.

PINHEIRO, Armando Castelar et Saddi, Jairo. Direito, Economia e Mercados. $4^{\mathrm{a}}$ Ed., Rio de Janeiro: Editora Campus, 2006.

EIZIRIK, Nelson. Administração de cartão de crédito constitui atividade privativa de instituição financeira? Revista de Direito Mercantil, Industrial, Econômico e Financeiro. São Paulo: RT, 1992, n. 88.

NETO, Eduardo Salomão. Direito Bancário. $1^{\circ}$ Ed., São Paulo, Editora Atlas.

TEPEDINO, Gustavo, et. al. Código Civil Interpretado. $2^{\mathrm{a}}$ Ed., Rio de Janeiro: Editora Renovar, vol. 2.

COSTA, JUDITH MARTINS. Comentários ao Novo Código Civil. $2^{\mathrm{a}}$ Ed., Rio de Janeiro: Editora Forense, 2009.

JÚNIOR, WALDO FAZZIO. Cartão de crédito, cheque e direito do consumidor. São $\quad$ Paulo: $\quad$ Editora 2011. 
VENOSA, Sílvio de Salvo. Direito Civil. $8^{\circ}$ ed., vol. 2. São Paulo, 2008.

EFING, Antônio Carlos. Contratos e Procedimentos Bancários à luz do Código de Defesa do Consumidor. São Paulo. Revista dos Tribunais, 2012.

MARQUES, Cláudia Lima. Contratos no Código de Defesa do Consumidor: o novo regime das relações contratuais. São Paulo: Revista dos Tribunais, 2005.

\section{Jurisprudência}

Apelação $n^{\circ}$ 1.155.678-0/0, 26 Câmara Cível do Tribunal de Justiça do Estado de São Paulo. Ilmo. Des. ANDREATTA RIZZO. 14.04.2008.

Apelação $\mathrm{n}^{\circ}$ 7.175.323-8, 19 ${ }^{\mathrm{a}}$ Câmara Cível do Tribunal de Justiça do Estado de São Paulo. Ilmo. Des. RICARDO NEGRÃO. 27.11.07.

Apelação $\mathrm{n}^{\mathrm{o}}$ 2008.001.47906, $5^{\mathrm{a}}$ Câmara Cível do Tribunal de Justiça do Estado do Rio de Janeiro. Ilma. Des. Rel. TERESA CASTRO NEVES. 20.10.08.

Apelação $n^{0}$ 9121827-44.2008.8.26.0000, 25ª Câmara Cível do Tribunal de Justiça do Estado de São Paulo. Ilmo. Des. Rel. VANDERCI ÁLVARES. 20.06.12.

Apelação $n^{0}$ 0005711-61.2012.8.19.0001, 15 Câmara Cível do Tribunal de Justiça do Estado do Rio de Janeiro. Ilmo. Des. Rel. JACQUELINE LIMA MONTENEGRO. 26.06.12. 
Recurso Especial 1.058.221/PR, Superior Tribunal de Justiça. Ilma. Min. NANCY ANDRIGHI. 04.10.11.

Recurso Especial 1.165.279/SP, Superior Tribunal de Justiça. Ilmo. Ministro TARSO SANSEVERINO. 22.05.12.

Recurso Especial 1.029.454/RJ, Superior Tribunal de Justiça. Ilma. Min. NANCY ANDRIGHI. 19.10.09. 


\section{Anexo I}

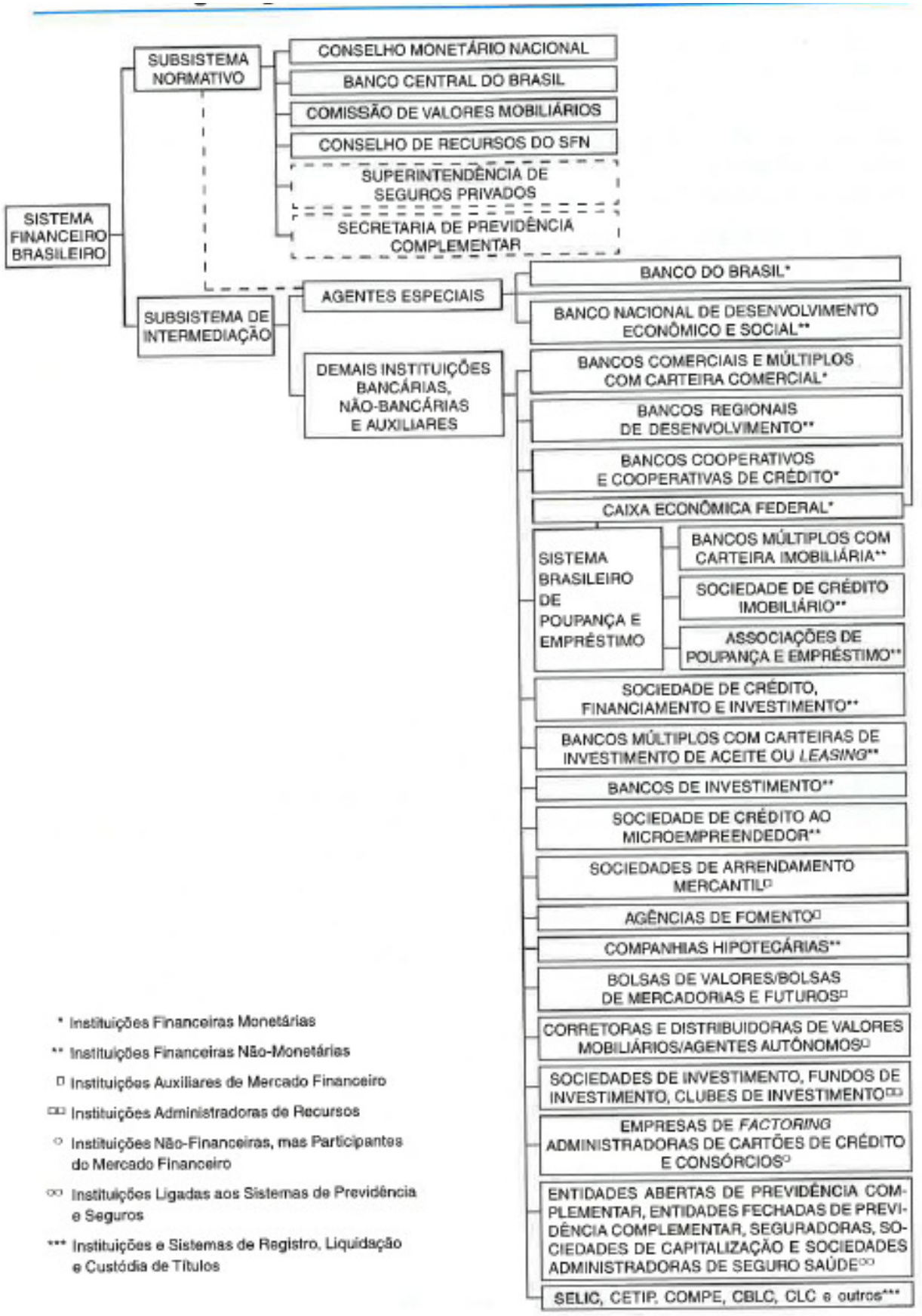




\section{Anexo II}

\section{“Instrumento Particular de Prestação de Serviços de Gestão de Pagamentos e Outras Avenças \\ 1 - PARTES}

AKATUS MEIOS DE PAGAMENTO S.A. (adiante apenas AKATUS), pessoa jurídica de direito privado, com sede na cidade de São Paulo, Estado de São Paulo, na Rua Dr. Cardoso de Melo, $n^{\circ} 1460,9^{\circ}$ andar, Bairro Vila Olímpia, CEP 04.548-004, inscrita no CNPJ/MF sob o número 14.576.597/0001-21, na condição de mantenedora de uma Plataforma de Pagamentos;

VENDEDOR, pessoa física ou jurídica que atua, profissionalmente ou não, no comércio de produtos e/ou serviços e que utiliza a Plataforma de Pagamentos da AKATUS como ferramenta de recebimento do preço dos produtos ou da remuneração pelos serviços; e

COMPRADOR, terceiro interessado no presente Termo, do qual declara ciência e aceitação de todas as suas condições, pessoa física ou jurídica que deseje adquirir produtos e/ou serviços ofertados por um VENDEDOR com o emprego da Plataforma de Pagamentos da AKATUS para realização do pagamento,

Têm entre si, justo e acordado, celebrar o presente Instrumento Particular de Prestação de Serviços de Gestão de Pagamentos e Outras Avenças, doravante denominado simplesmente Termos e Condições de Uso, que se regerá pelas cláusulas e condições seguintes.

\section{2 - OBJETO}

2.1. Pelo presente Instrumento, a AKATUS disponibiliza para o VENDEDOR, por si própria ou por intermédio de empresa por ela contratada, de forma não exclusiva, sua Plataforma de Pagamentos, que consiste em uma ferramenta tecnológica cuja função é realizar a gestão de meios de pagamentos e recebimentos on-line e gerenciar os referidos pagamentos e recebimentos.

Sempre que o VENDEDOR disponibilizar o sistema de recebimento de pagamentos da AKATUS a um COMPRADOR, estará nomeando AKATUS como sua mandatária para receber o pagamento em nome do VENDEDOR, devendo a AKATUS, para o fiel cumprimento desse mandato, empregar a melhor técnica e tecnologia com vistas à preservação dos direitos e interesses do VENDEDOR. Sempre que o COMPRADOR decidir realizar um pagamento a um VENDEDOR com o emprego da Plataforma de Pagamentos, estará nomeando AKATUS como sua legítima mandatária para o fim de receber os pagamentos por sua conta e ordem e os transmitir ao seu destinatário final, o VENDEDOR.

2.1.1 . O serviço prestado pela AKATUS não se confunde com aqueles prestados pelas empresas de meios de pagamento (adquirentes e administradoras de cartão de crédito, por exemplo). A AKATUS apenas presta os serviços de gerenciamento desses meios de pagamento, repassando aos VENDEDORES os recebimentos em razão da venda e compra de bens e/ou serviços on-line, via internet. 
2.2. Para a utilização e acesso à Plataforma de Pagamentos, o VENDEDOR deverá possuir o equipamento necessário, inclusive computador ou telefone celular do tipo "smartphone", com acesso à Internet, provedor de conexão à Internet, equipamentos, acessórios e softwares, sendo que o VENDEDOR é o único responsável pela obtenção, manutenção e custeio do referido equipamento, mesmo quando a AKATUS lhe oferecer eventual suporte ou auxílio em seu desenvolvimento, bem como por verificar se a sua configuração satisfaz os requisitos aqui previstos para fruição dos serviços ora prestados e por eventuais danos que venham a incorrer em seu equipamento em decorrência do mau uso de qualquer hardware, software ou conexões.

2.3. O VENDEDOR deverá dispor de um dos meios necessários para acesso e integração ao serviço prestado pela AKATUS, tais como Checkout (post), Webservice e NPI (post e soap $1.1)$.

\section{3 - HABILITAÇÃO DE VENDEDOR}

3.1. Podem habilitar-se como VENDEDORES da Plataforma de Pagamentos da AKATUS:

(i) as pessoas físicas consideradas capazes nos termos do Código Civil Brasileiro, ou as relativamente incapazes, desde que assistidas por seus pais, responsáveis, tutores ou curadores.

(ii) as pessoas jurídicas devidamente constituídas, com sede ou escritório comercial no território nacional (Brasil), desde que representadas por quem tenha poderes para realizar as operações objeto do presente Instrumento;

3.1.1. Não podem habilitar-se como VENDEDOR as pessoas absolutamente incapazes, incluindo-se menores de idade.

3.2. O VENDEDOR preencherá seu cadastro fornecendo um endereço de e-mail válido e informações precisas e verídicas, se comprometendo a atualizar referidos dados sempre que houver uma alteração. O VENDEDOR responsabiliza-se civil e criminalmente pelas informações prestadas no cadastro e demais formulários da AKATUS.

3.3. É de inteira e exclusiva responsabilidade do VENDEDOR a manutenção de confidencialidade e segurança de sua senha e identificação, as quais deverão ser informadas sempre que o VENDEDOR desejar utilizar o serviço ora oferecido pela AKATUS.

3.4. Para efetuar o cadastro na AKATUS, o VENDEDOR deverá fornecer conta bancária de sua titularidade, não podendo ser utilizada conta bancária de titularidade de terceiros, bem como referida conta deverá ser mantida no Brasil junto a uma instituição financeira devida e regularmente constituída ou autorizada a funcionar no território nacional.

3.5. A AKATUS não exerce a função de verificação de restrições creditícias e não se responsabiliza pela solvência e adimplemento dos COMPRADORES que façam uso da "Plataforma de Pagamento" em face do VENDEDOR.

3.6. A AKATUS, ao seu exclusivo critério, poderá negar a habilitação de um VENDEDOR, bem como encerrar habilitação já existente, sem que surja para o VENDEDOR qualquer direito de indenização ou ressarcimento a qualquer título, especialmente quando entender 
que a continuidade da manutenção do cadastro de VENDEDOR poderá representar uma diminuição da segurança para AKATUS e/ou para os demais VENDEDORES da Plataforma.

3.7. O VENDEDOR não poderá ter mais de um Cadastro sob sua titularidade ao mesmo tempo. A AKATUS reserva-se o direito de unificar os Cadastros e/ou cancelar logins do VENDEDOR, caso tenha sido atribuído ao VENDEDOR que já tenha um Cadastro um outro Cadastro. A AKATUS poderá não aceitar cadastramento que informe o mesmo endereço de e-mail ou o mesmo CPF ou CNPJ de VENDEDOR já cadastrado ou que informe outros dados que indiquem que o VENDEDOR já está cadastrado junto a AKATUS.

3.7.1. Caso o VENDEDOR mantenha mais de um cadastro, manifesta ciência e anuência ao fato de que AKATUS poderá trata-los como um só, inclusive buscando fundos em um deles para recompor débitos originados nas operações do outro.

3.8. O VENDEDOR poderá transacionar imediatamente após a efetivação de seu cadastro, mediante confirmação do link enviado ao e-mail cadastrado, que ativará sua conta. No entanto, para ter acesso aos valores relativos às transações realizadas e efetuar saques para sua conta bancária ou cartão Akatus ou até mesmo efetuar transferências entre contas Akatus, sua conta deverá ser verificada. Para tanto, o VENDEDOR deverá invariavelmente enviar os documentos solicitados pela equipe de análise da Akatus, nos moldes e formato indicados na página de Documentação no Painel de Controle de sua conta Akatus, conforme Anexo I ao presente Termo.

3.9. A AKATUS reserva-se o direito de utilizar todos os meios válidos e possíveis para, se entender necessário, confirmar os dados fornecidos pelo VENDEDOR quando de seu cadastramento. A AKATUS poderá, entre outras medidas, solicitar ao contratante dados adicionais e documentos que julgue pertinentes, previamente à primeira liberação dos créditos do VENDEDOR, bem como consultar bancos de dados mantidos por terceiros e bases de restrições creditícias, tais como SPC e Serasa. Caso a AKATUS constate haver, entre as informações fornecidas pelo VENDEDOR, informações incorretas inverídicas ou falsas, caso o VENDEDOR deixe de enviar à AKATUS os documentos solicitados ou a AKATUS constate sejam estes documentos falsos ou com qualquer indício ou suspeita de fraude ou adulteração dos mesmos, ou caso a AKATUS constate haver restrições ao crédito do VENDEDOR, a AKATUS poderá, a seu livre critério, rejeitar, bloquear ou cancelar o Cadastro do VENDEDOR, independentemente de prévia notificação, sem prejuízo de outras medidas previstas no presente Termo, e sem que assista ao VENDEDOR qualquer sorte de indenização ou ressarcimento.

3.10. O VENDEDOR e o COMPRADOR, neste ato, autorizam expressamente que seus dados sejam mantidos pela AKATUS, bem como autorizam seu fornecimento (i) às autoridades públicas competentes que os solicitarem formalmente, nos termos da legislação brasileira; (ii) aos seus parceiros estratégicos, comerciais ou técnicos, com a finalidade de disponibilizar melhores conteúdos ao VENDEDOR e ao COMPRADOR. O VENDEDOR e o COMPRADOR concordam expressamente, também, que a AKATUS colete informações para a realização de acompanhamento de tráfego, com o intuito de identificar grupos de perfil de VENDEDORES e para fins de estudos e orientações publicitárias.

3.11. AKATUS não se responsabiliza pela regularidade do cadastro do VENDEDOR junto aos órgãos e Autoridades competentes, tais como Junta Comercial, Fiscos Municipal, 
Estadual e Federal, etc.

3.12. Caso o cadastro do VENDEDOR seja utilizado em um ambiente em que outras pessoas, mediante contratação direta com o VENDEDOR, dele possam usufruir, tais como em plataformas coletivas de comércio eletrônico, o VENDEDOR manifesta integral ciência e anuência ao fato de que toda atitude tomada com a utilização de seu cadastro será de sua inteira e exclusiva responsabilidade, respondendo por ela inclusive pessoalmente ou na pessoa de seus sócios.

3.13. A AKATUS disponibiliza para VENDEDORES Mobile a opção de cadastro de "subvendedores" (denominada Cadastro de Vendedores no site Akatus). Solução a qual um titular da conta AKATUS pode cadastrar vendedores abaixo de sua conta Akatus, criando assim uma estrutura de equipe de vendas, onde todas as transações efetuadas por "sub-vendedores" são automaticamente direcionadas e contabilizadas exclusivamente na conta titular. Portanto "Sub-Vendedores" não terão acesso à Conta Akatus (Painel de Controle), por esse motivo não efetuarão saques ou transferências.

3.13.1. O Titular da conta AKATUS é e será responsável pelo cadastro, bloqueio, desbloqueio e alteração das informações dos "sub-vendedores" por ele cadastrado, bem como será o único responsável direto sobre toda e qualquer transação efetuada pelos seus "subvendedores", assumindo assim responsabilidades sobre estornos, cancelamentos, chargebacks e demais atividades referentes as transações.

3.13.2. Denominam-se "sub-vendedores", aqueles vendedores cadastrados abaixo de uma Conta Vendedor AKATUS (Conta Titular).

\section{4 - VIGÊNCIA, ALTERAÇÕES E RESCISÃO DO TERMO}

4.1. Os presentes Termos têm início com a concordância, pelo VENDEDOR de suas disposições, o que o faz ao clicar em "Li e Aceito", confirmando a mesma manifestação de vontade toda vez que de alguma forma utilizar a Plataforma de Pagamentos. Os Termos e Condições de Uso têm prazo de duração indeterminado, podendo ser rescindidos por qualquer das partes sem aviso prévio, sem prejuízo do integral cumprimento pelas partes das obrigações resultantes do presente contrato e contraídas no período de vigência do contrato.

4.2. Para o VENDEDOR, a rescisão se dará com a solicitação de encerramento de seu cadastro junto à AKATUS, que deverá ser realizada por meio do site www.akatus.com.br, no link https://www.akatus.com/contato e que se processará em até 48 horas após recebida a solicitação pela AKATUS.

4.3. Conforme estipulado neste Termo, a AKATUS poderá, a seu exclusivo critério, encerrar o cadastro do VENDEDOR (fazendo cessar, portanto, sua utilização da Plataforma de Pagamentos), sem notificação prévia nos casos em que o VENDEDOR tenha infringido as disposições constantes do presente Instrumento e da legislação, especialmente quando constatar que qualquer documento enviado pelo VENDEDOR for falso ou contiver qualquer indício ou suspeita de fraude ou adulteração, sem prejuízo da realização pela AKATUS de eventuais denúncias aos órgãos competentes no caso de configuração de infração penal, aos direitos do consumidor, ao meio ambiente ou qualquer outra infração à legislação vigente, à moral e aos bons costumes. 
4.4. Os presentes Termos também serão rescindidos, independentemente de qualquer notificação, no caso de o VENDEDOR, de qualquer forma, comprometer a imagem pública da AKATUS e/ou de qualquer empresa associada à AKATUS na prestação do presente Serviço. A rescisão dos presentes Termos, por qualquer motivo, não prejudicará o direito da AKATUS de haver as quantias porventura devidas pelo VENDEDOR e/ou COMPRADOR relativamente ao serviço prestado pela AKATUS anteriormente à rescisão, nem o de haver a indenização porventura devida pelo VENDEDOR.

4.5. A AKATUS poderá, a seu critério exclusivo e independentemente de notificação, modificar, adicionar ou remover quaisquer cláusulas, condições ou anexos deste Instrumento. Quando a alteração implicar em restrição das condições inicialmente pactuadas ou alteração nos valores, a AKATUS informará as novas condições ao VENDEDOR com, no mínimo, 30 (trinta) dias de antecedência da data pretendida para a revisão através de e-mail. Caso o VENDEDOR não concorde com os novos valores e condições informadas pela AKATUS, ele poderá rescindir o presente Termo dentro do prazo dos mesmos 30 (trinta) dias. Caso não solicite a rescisão do presente Termo dentro do prazo estipulado, entender-se-á que o VENDEDOR aceitou tacitamente os novos valores e condições da AKATUS.

\section{5 - REMUNERAÇÃO}

5.1. A título de remuneração pela disponibilização de sua Plataforma de Pagamentos e pela prestação dos serviços de mandato para gestão e gerenciamento dos pagamentos/recebimentos, bem como para a remuneração das empresas de meio de pagamento, o VENDEDOR arcará com os valores constantes da "Tabela de Valores", na página http://www.akatus.com/como-funciona, de acordo com o pacote de pagamentos por ele selecionado quando do seu cadastramento.

5.2. A Akatus atua como mera gestora de meios de pagamento, agindo sempre como mandatária do VENDEDOR, sendo remunerada por essa função. Uma parcela dos valores constantes da "Tabela de Valores" será devida diretamente pelo VENDEDOR às empresas de meio de pagamento. As próprias empresas de meio de pagamento realizam desconto do valor total da Transação, de modo que este valor não se caracteriza, sob qualquer hipótese, receita própria da AKATUS.

5.3. Conforme disposto neste item, a AKATUS terá a sua remuneração calculada e devida em função de porcentagens previamente estabelecidas a incidirem sobre o valor das Transações realizadas na Plataforma de Pagamentos entre o VENDEDOR e o COMPRADOR, não sendo cobrado nenhum valor a título de cadastramento do VENDEDOR ou de qualquer tipo de mensalidade pela prestação do serviço.

5.4. Este instrumento não isenta o VENDEDOR de arcar com os custos e as despesas não diretamente relacionados ao serviço, tais como o acesso e conexão à internet.

5.5. A AKATUS não realizará qualquer pagamento a VENDEDORES não cadastrados e/ou que não aceitem expressamente o objeto do presente contrato como forma de pagamento pelos bens e/ou serviços que oferecerem, e/ou que não tenham fornecido todos os documentos solicitados pela AKATUS, observada a devida conformidade destes com os critérios estipulados pela AKATUS.

5.6. Somente poderão ser feitos Pagamentos a VENDEDORES localizados no território nacional, devendo o preço das Transações que utilizarão a Plataforma de Pagamento da 
AKATUS ser sempre expresso em moeda corrente nacional (atualmente, Reais, ou R\$). Não serão realizados, em hipótese alguma, quaisquer Pagamentos a VENDEDORES que não estejam localizados no território nacional, ou por Transações que utilizem a Plataforma de Pagamento da AKATUS cujo preço não esteja expresso em moeda corrente nacional.

5.7. Não serão realizados, em hipótese alguma, quaisquer pagamentos ao VENDEDOR caso este não esteja apto a recebê-los no território nacional, bem como não serão realizados pagamentos a conta bancárias de titularidade de terceiros, que não estejam em nome do VENDEDORES ou que seja mantida em instituição fora do território nacional e/ou não regularmente constituída ou autorizada a funcionar no território brasileiro.

\section{DA TRAnSAÇÃo ATRAVÉS dA Plataforma de PAgamento da AKATUS}

6.1. O Serviço ora prestado tem como premissa que o VENDEDOR, quando atuar como comerciante de produtos ou serviços, faça constar em suas ofertas publicitárias todas as informações relevantes para a tomada de decisão do comprador e cumpra estritamente com todas as condições a que se comprometeu, seja por contrato, seja na oferta publicitária. Reconhece o VENDEDOR que a AKATUS poderá suspender, reverter ou glosar qualquer valor ou expectativa de valor ao VENDEDOR caso o COMPRADOR informe a AKATUS, na forma estabelecida neste Termo, que a Transação não foi cumprida conforme ofertada ou que haja no produto ou serviço entregues vícios, defeitos ou disparidades com a descrição constante da oferta. Neste caso, o VENDEDOR declara estar ciente de que arcará com todo e qualquer custo, despesa ou taxas eventualmente relacionadas com o descumprimento da Transação, nos Termos deste Contrato, inclusive garantindo a isenção de responsabilidade da AKATUS por eventuais disputas administrativas, criminais ou judiciais, assumindo integralmente as despesas de defesa suportadas pela AKATUS e reconhecendo sua condição de litisconsorte necessário nos termos do artigo 70, III do Código de Processo Civil Brasileiro, cabendo a ação de regresso quando o litisconsórcio não for possível.

6.2. Para operações no ambiente online, observar-se-á os procedimentos explanados a seguir:

6.2.1. Após o VENDEDOR ter optado por realizar uma Transação através da Plataforma de Pagamento da AKATUS, o COMPRADOR, utilizando o ambiente Internet, será direcionado ao site da AKATUS e informará os dados que lhe forem solicitados. Após o envio das informações e confirmação pela AKATUS, a Transação ficará pendente de análise. A AKATUS não se responsabiliza pelas consequências de quaisquer imprecisões ou erros nas informações que the houver prestado o VENDEDOR ou o COMPRADOR.

6.2.2. Uma vez verificada a conformidade do procedimento, será autorizado o Pagamento ao VENDEDOR através da Plataforma de Pagamento da AKATUS dentro do prazo acordado, em conformidade com o pacote de pagamento adquirido quando do seu cadastramento. Referida autorização será confirmada em e-mail a ser enviado ao VENDEDOR e ao COMPRADOR.

6.3. O VENDEDOR está ciente de que deve cumprir suas obrigações legais e contratuais decorrentes da Transação, zelando pela alta qualidade, bem como pela segurança e satisfação do COMPRADOR. Desta forma, caso, ao realizar qualquer Transação através da Plataforma de Pagamento da AKATUS, não entregue no prazo contratado os bens e/ou serviços vendidos, o VENDEDOR, sem prejuízo das medidas que a AKATUS possa tomar segundo o presente contrato, deverá informar a AKATUS, esclarecendo os motivos e passando a 
envidar seus melhores esforços para que problemas deste tipo não ocorram novamente e nem prejudiquem outros VENDEDORS e/ou COMPRADORES e/ou quaisquer outros terceiros interessados.

6.4. O VENDEDOR declara-se ciente de que, entre o $15^{\circ}$ (décimo quinto) e o $30^{\circ}$ (trigésimo) dia após a comunicação da confirmação da transação, a ser encaminhada via e-mail, a AKATUS poderá suspender, reverter, ou cancelar transações do VENDEDOR, caso o COMPRADOR a informe de que o VENDEDOR não lhe entregou os bens ou serviços vendidos conforme os termos acordados.

6.5. Caso, no momento em que AKATUS receber, de qualquer COMPRADOR, na forma prevista neste Termo, a informação sobre a falta de entrega do bem ou serviço adquirido, o Pagamento ainda não tenha sido realizado, a AKATUS terá o direito de bloquear o Pagamento e estornar os valores referentes à Transação denunciada ao COMPRADOR, sem que haja possibilidade de estorno ou suspensão dos pagamentos devidos pelo VENDEDOR à AKATUS referente à Transação.

6.6. Implicações ao COMPRADOR quando da Transação:

6.6.1. Após o envio do e-mail de confirmação da transação, caso o prazo para entrega do bem ou serviço adquirido com o emprego da Plataforma de Pagamento da AKATUS expire sem o seu recebimento antes do prazo estabelecido na cláusula 6.4 para a realização do pagamento, o COMPRADOR deverá imediatamente informar a AKATUS, através dos mecanismos disponíveis no endereço eletrônico cancelamento@akatus.com a fim de que a AKATUS possa verificar o ocorrido, suspender o pagamento e estornar os valores referentes à Transação denunciada efetuada através da Plataforma de Pagamento da AKATUS.

6.6.2. Após o envio do e-mail de confirmação da transação, se o prazo para entrega do bem ou serviço adquirido com o emprego da Plataforma de Pagamento da AKATUS expirar após o prazo estabelecido na cláusula 6.4 para a realização do Pagamento, o COMPRADOR deverá imediatamente informar a AKATUS através dos mecanismos disponíveis no endereço eletrônico cancelamento@akatus.com, a fim de que a AKATUS possa verificar o ocorrido e, caso tenha decorrido prazo inferior a 30 dias desde a comunicação de aprovação da Transação, a AKATUS envidará seus melhores esforços no sentido de cancelar o Pagamento e estornar os valores referentes à Transação denunciada efetuada através da Plataforma de Pagamento da AKATUS.

6.6.3. O COMPRADOR será o único responsável pelas consequências de sua ordem de suspender o pagamento consoante as subcláusulas i e ii da presente cláusula, devendo manter a Akatus isenta de qualquer responsabilidade perante ele próprio, o VENDEDOR e quaisquer outros terceiros envolvidos.

6.7 . A AKATUS não garante a prestação dos serviços e a disponibilização de seus sistemas e de sua Plataforma de Pagamentos de forma ininterrupta ou isenta de erros e não se responsabiliza pela impossibilidade de realização de transações durante os períodos de indisponibilidade.

6.8. A AKATUS se reserva no direito de não efetuar Cancelamentos/Estornos no período de 90 dias após a data da transação, conforme acordo firmado com operadoras de cartões. Após o período de 90 dias da data da transação apenas e exclusivamente o VENDEDOR é responsável pelo Cancelamento/Estorno da transação em questão. 
6.9. A AKATUS se reserva no direito de não efetuar Cancelamentos/Estornos no período de 7 dias após a data do pagamento de Boleto Bancário, conforme regras do CDC. Após o período de 7 dias da data de pagamento, apenas e exclusivamente o VENDEDOR é responsável pelo Cancelamento/Estorno da transação em questão.

6.10. Na utilização da Plataforma de Pagamento AKATUS Mobile, o VENDEDOR manifesta ter conhecimento de sua obrigação de conferir a titularidade do cartão de crédito apresentado pelo COMPRADOR, asseverando que a identidade dele coincide com a do titular do cartão.

\section{7 - DA POLÍTICA DE “CHARGEBACK”}

7.1. De acordo com regras de avaliação e monitoramento de desempenho da conta do VENDEDOR, estabelecidas pela AKATUS, o VENDEDOR será informado, via e-mail, em caso de ações pós análise para correção de taxas, notificação de bloqueio de meios de pagamento, retirada da proteção de chargeback, notificação de bloqueio de acesso (definitivo ou temporário) ou outras que julgue necessário.

7.2. O VENDEDOR estará protegido do chargeback quando:

1. Enviar comprovação válida de entrega de bem e/ou serviço, no prazo de 48 horas, quando solicitado pela AKATUS;

2. Comprovar a necessidade de participação do COMPRADOR na especificação de bem e/ou serviço, e este ainda não o tenha feito;

3. Possuir Aviso de Recebimento do bem e/ou serviço assinado pelo COMPRADOR;

4. Informar o código válido do rastreio de envio de bem e/ou serviço, a ser confirmado pelo site dos Correios e/ou da transportadora responsável;

5. Enviar cópia da nota fiscal emitida referente à transação realizada;

6. Efetuar a entrega do bem e/ou serviço apenas nos endereços cadastrados na AKATUS; e,

7. Enviar toda a documentação solicitada pela AKATUS para que esta possa efetuar a contestação do chargeback.

7.3. O VENDEDOR será responsável pelo chargeback quando:

1. Não enviar resposta às solicitações e questionamentos da AKATUS, dentro do prazo de 48 horas, conforme cláusula anterior;

2. Informar Aviso de Recebimento e código de rastreamento do bem e/ou serviço inválido e/ou sem assinatura do COMPRADOR;

3. Efetuar a entrega do produto em endereço diferente daquele cadastrado na AKATUS;

4. Efetuar o cadastramento na AKATUS em nome do COMPRADOR e a contestação vir em nome do portador do cartão de crédito;

5. Não efetuar o cancelamento por solicitação da AKATUS de uma transação já aprovada, na qual posteriormente seja identificada fraude, informada pelo emissor do cartão de crédito, vindo esta a gerar chargeback;

6. Estiver ofertando à venda bens e/ou serviços que não estejam de acordo com as descrições veiculadas aos compradores;

7. Houver cancelamento da prestação de serviços sem aviso prévio e/ou sem informe de nova data a ser realizada;

8. Houver políticas do VENDEDOR quanto à devolução de um bem e/ou do valor de um serviço, ou termos e condições de um contrato, tais como garantia de cem por cento de devolução em dinheiro por serviços não prestados, ou políticas de devolução não estão claras; 
9. COMPRADOR comprovar, via e-mail, que efetuou a solicitação do cancelamento da compra no prazo de até 7 dias a contar de sua assinatura ou do ato de recebimento do bem ou serviço, como garante o artigo 49 do Código de Defesa do Consumidor, e esta não for realizada pelo VENDEDOR;

10. Entregues pelo VENDEDOR, os bens forem extraviados, avariados ou não puderem ser usados para a finalidade a que se destinavam;

11. O portador do cartão de crédito comprovar, via Aviso de Recebimento registrado, que devolveu o bem ao VENDEDOR e/ou comprovar que houve tentativa de resolução do problema original com o bem e/ou serviço e não houve resposta do VENDEDOR;

12. O VENDEDOR não divulgar, apropriadamente, possíveis atrasos na entrega do bem e/ou serviços;

13. O VENDEDOR comercializar bens diferentes do informado e dos que constam no site; e, 14. O VENDEDOR desmembrar o preço de uma mesma transação em mais de um lançamento, havendo quebra do valor que possa ser identificada pelo COMPRADOR como duplicidade de transação.

15. Não encaminhar à AKATUS a cópia da nota fiscal emitida referente à transação realizada

7.4. Independente das cláusulas acima constantes deste item, as partes poderão convencionar regramentos adicionais ou celebrar contrato com regras próprias de chargeback,.

\section{8 - RESTRIÇÃO DE ATIVIDADES}

8.1. É terminantemente proibida a utilização da Plataforma de Pagamentos da AKATUS para a realização de atividades que sejam consideradas ilegais ou fraudulentas, que desrespeitem a legislação brasileira e/ou do local onde esteja sendo realizada, e que digam respeito, de qualquer forma, incluindo, mas não se limitando, ao quanto segue:

1. Atividades de comércio de produtos em que o ofertante dos mesmos não os tenha em estoque no momento da oferta;

2. Atividades de comércio em caráter profissional sem a emissão de Nota Fiscal;

3. Atividades ou produtos que desrespeitem as normas relativas à transmissão de dados, aos direitos autorais ou de propriedade industrial;

4. Atividades contrárias à moral e aos bons costumes;

5. A transmissão ou propagação de informações sobre atividades ilegais, inclusive instruções de como se cometer crimes ou contravenções, bem como a incitação ao crime, a apologia ao crime ou a criminosos;

6. Atividades que denotem ou promovam o preconceito de raça, cor, etnia, religião ou origem, ou que incitem à violência ou ao ódio;

7. Atividades que transmitam ou propaguem material ilegal, calunioso, injurioso, difamatório, prejudicial, abusivo, ameaçador, vulgar, indecente, obsceno, ou de qualquer outra forma censurável;

8. O envio de material publicitário não solicitado, inclusive spam, junk mail, correntes de correspondência (chainletters) ou pirâmides;

9. A transmissão de programas ou arquivos que contenham vírus, a obtenção ou tentativa de obtenção de acesso não autorizado aos sistemas ou redes conectados à AKATUS, a realização de atos que prejudiquem ou busquem prejudicar ou interromper o serviço da AKATUS, ou que exponha sua infraestrutura a sobrecarga, atividades de hacking e craking; 10. Atividades que infrinjam os direitos autorais, copiem, reproduzam ou modifiquem qualquer conteúdo do site da AKATUS ou de terceiro conectado à AKATUS sem a expressa autorização;

11. Valores mobiliários, serviços bancários e financeiros e captação de investimentos, 
seguros de qualquer natureza;

12. Comércio de animais silvestres, ou que não tenham sua comercialização autorizada pelo IBAMA ou órgão correspondente no exterior, ou ainda que tenham seu comércio autorizado apenas em circunstâncias especiais, bem como seus órgãos, membros e peles;

13. Comércio de antenas, sistemas decodificadores ou quaisquer dispositivos que tenham por finalidade decodificar sinais de transmissão;

14. Comércio de bancos de dados e listas de correio que contenham dados pessoais;

15. Jogos de azar, conforme definidos pela legislação brasileira;

16. Comércio de diplomas e certificados;

17. Ofertas de cartões de crédito ou débito, ativos ou não, e serviços correlatos;

18. Comércio de cópias não autorizadas de músicas, áudio, vídeo ou imagens;

19. Serviços de factoring e afins;

20. Comércio de fogos de artifício ou qualquer outro tipo de material explosivo, bem como armas de fogo e munições;

21. Comércio de medicamentos e utensílios destinados a produção, manipulação ou consumo de medicamentos, bem como qualquer produto ao qual se atribua efeito terapêutico;

22. Comércio de moedas e cédulas, nacionais ou estrangeiras (excluindo-se material colecionável), falsificações ou imitações;

23. Comércio de produtos químicos de venda controlada, narcóticos, tóxicos, substâncias alucinógenas, bem como materiais para sua utilização ou produção, anabolizantes e esteroides;

24. Comércio de pessoas, órgãos, tecidos, membros e produtos do corpo humano;

25. Atividade de prostituição;

26. Comércio de trabalhos acadêmicos;

27. Comércio de veículos automotores que possuam restrições documentárias;

28. Comércio de produtos relacionados à pedofilia, pornografia infantil, nudez de menores;

29. Comércio de itens do patrimônio histórico, artístico e cultural, incluindo fósseis;

30. Comércio de produtos furtados, roubados, subtraídos ou de qualquer maneira receptados, contrabandeados, falsificados, replicados ou adulterados;

31. Comércio de produtos submetidos a embargos ou que dependam de prévia homologação ou autorização governamental para sua comercialização.

8.2. Independentemente de sua ilicitude, a AKATUS poderá retirar ou acrescentar itens na listagem constante da cláusula anterior.

8.3. O VENDEDOR não poderá alterar endereços de máquinas, ou o Internet Protocol de rede ou de correio eletrônico, na tentativa de responsabilizar terceiros ou ocultar sua identidade ou autoria. Em qualquer dessas hipóteses, a AKATUS poderá disponibilizar, a qualquer tempo, às autoridades competentes, toda e qualquer informação sobre o VENDEDOR, bem como encerrar sua habilitação sem notificação prévia, nos termos do item 4 do presente Termo.

8.4. Caso haja indício de ilicitude, fraude ou violação ao presente contrato por parte do contratante, a AKATUS poderá suspender a realização de qualquer pagamento ou movimentação, até que se esclareça a situação.

8.5. O VENDEDOR assume toda a responsabilidade, civil e criminal, perante a AKATUS, o COMPRADOR e quaisquer terceiros pelo descumprimento de suas obrigações e/ou pela inexatidão de suas declarações ou por qualquer outra conduta ilícita.

8.6. O VENDEDOR indenizará a AKATUS de quaisquer prejuízos, inclusive despesas, 
honorários de advogados e custas judiciais, sofridos pela AKATUS em decorrência do descumprimento das obrigações contratuais ou legais do VENDEDOR, da inexatidão das declarações do VENDEDOR ou de reclamações de terceiros relativas à conduta do VENDEDOR, sem prejuízo do direito da AKATUS de rescindir o presente contrato conforme estabelecido no item 4 do presente Termo.

9 - DIREITOS AUTORAIS E DE PROPRIEDADE INTELECTUAL $\square$ 9.1. O site www.akatus.com.br, a Plataforma de Pagamentos da AKATUS, bem como as marcas, logotipos e demais conteúdos do site são de propriedade da AKATUS ou de seus provedores e estão protegidos pelas normas de direitos autorais, direitos de marca e de propriedade intelectual e demais normas aplicáveis, sendo vedada a sua reprodução, cópia ou qualquer outra forma de utilização comercial ou divulgação não autorizada.

9.2. Todos os direitos sobre os conteúdos do site ou em conexão a estes são de exclusiva propriedade da AKATUS. Exceto se dentro dos exatos termos deste Instrumento, o VENDEDOR não terá nenhum direito, título ou interesse, expresso ou tácito, em relação aos conteúdos e a sua utilização, e não deverá, em nenhum momento, após a vigência deste Instrumento, assumir ou pleitear nenhum direito de explorar, vender ou colocar à venda os conteúdos, sem a expressa autorização de seus detentores.

9.3. É terminantemente proibida a utilização de logomarcas, marcas e outras peças em nome da AKATUS além daquelas disponibilizadas pela própria AKATUS.

\section{0 - POLÍTICAS DE PRIVACIDADE E SEGURANÇA}

10.1. AKATUS zela pela privacidade e confidencialidade das informações coletadas de seus VENDEDORES e COMPRADORES. Dentre os dados coletados estão os dados informados no cadastro e os dados de pagamento, estes truncados para evitar sua reutilização. AKATUS compromete-se a utilizar tais dados apenas para o desenvolvimento regular de suas atividades e para a melhoria dos serviços que presta, abstendo-se de comercializar tais informações sob qualquer rubrica e informando-os exclusivamente em caso de interpelação oficial (policial, judicial ou por órgãos de defesa do consumidor, membros de Ministério Público e afins) ou para parceiros comerciais da AKATUS no desempenho de atividades relacionadas aos serviços da AKATUS.

10.2. O VENDEDOR isenta a AKATUS de toda e qualquer responsabilidade decorrente de casos fortuitos ou de força maior. A AKATUS não garante a disponibilidade e continuidade dos serviços, nem a inviolabilidade dos dados armazenados ou transmitidos por redes públicas de comunicação ou outras formas, bem como pelas falhas de funcionamento, vírus ou outros eventos que possam causar danos ao VENDEDOR.

10.3. A AKATUS fará todos os esforços razoáveis para assegurar que os prazos estimados para o processamento das operações sejam cumpridos, todavia, alguns fatores podem causar atrasos nos prazos estipulados para a realização dessas operações, estando o VENDEDOR ciente da possibilidade de tais atrasos, e, desde já eximindo a AKATUS de quaisquer responsabilidades.

10.4. A AKATUS não se obriga a realizar quaisquer operações que não estejam aprovadas pelo banco do COMPRADOR e não se responsabiliza por pagamentos efetuados de forma equivocada. 
10.5. A AKATUS adotará em todas as suas operações uma política específica para coibir a prática de "lavagem de dinheiro", sendo que toda e qualquer conduta considerada suspeita do VENDEDOR poderá ser comunicada às autoridades competentes, conforme o item 4 deste Instrumento.

10.6. O VENDEDOR obriga-se a tomar todas as precauções necessárias a fim de evitar que terceiros utilizem o Serviço ora prestado em seu nome. O VENDEDOR concorda em responsabilizar-se pelas Transações feitas em seu nome por terceiros, ainda que sem sua autorização, caso esses terceiros tenham, sem culpa exclusiva da AKATUS, tido aceso à senha ou outros dados do VENDEDOR que lhes tenham permitido realizar referidas Transações.

\section{1 - DECLARAÇÕES DO VENDEDOR}

11.1. Ao marcar a opção "Concordo com os termos do Instrumento Particular de Prestação de Serviços de Gestão de Pagamentos e Outras Avenças", constante do formulário de cadastro, o VENDEDOR declara ter lido e aceita, sem reservas, todas as cláusulas e condições previstas no presente Instrumento e seus anexos.

11.2. Neste ato, o VENDEDOR declara que todas as informações prestadas no ato de seu cadastramento são verdadeiras e que, nos termos do item 3 do presente Instrumento, está apto a habilitar-se como VENDEDOR.

11.3. O VENDEDOR declara ter ciência de que sua senha é pessoal e intransferível, sendo o único responsável pelo seu uso.

11.4. O VENDEDOR e o COMPRADOR declaram estar cientes de que, no caso de transações de comércio eletrônico, o serviço é prestado de forma a meramente facilitar e acompanhar o processo de realização da transação de comércio eletrônico entre VENDEDOR e COMPRADOR, e reconhecem que a transação de comércio eletrônico, quando efetivada, ocorrerá entre estes. O VENDEDOR e o COMPRADOR reconhecem, ainda, que a AKATUS não é parte da cadeia de fornecimento ou de consumo dos produtos ou serviços ofertados pelo VENDEDOR, não pode ser considerada fornecedora, prestadora, revendedora, adquirente ou usuária dos produtos ou serviços objeto das transações de comércio eletrônico, nem tampouco pode ser considerada agente, corretora ou de qualquer outra forma intermediária na relação entre o VENDEDOR e COMPRADOR. Em especial, o VENDEDOR e o COMPRADOR reconhecem que a AKATUS não tem nenhuma responsabilidade quanto:

1. Aos riscos, inclusive potencial nocividade ou periculosidade, aos defeitos, aos vícios de qualidade ou aos vícios de quantidade dos produtos ou serviços objeto das transações de comércio eletrônico do VENDEDOR

2. À insuficiência ou inadequação das informações referentes aos produtos ou serviços objeto das transações de comércio eletrônico do VENDEDOR

3. Às disparidades com as indicações constantes de ofertas ou mensagens publicitárias ou com as indicações constantes dos recipientes ou embalagens dos produtos ou serviços objeto das transações de comércio eletrônico do VENDEDOR

4. À inadequação dos produtos ou serviços objeto das transações de comércio eletrônico do VENDEDOR aos fins a que se destinam

5. A publicidade enganosa ou abusiva relativa aos produtos ou serviços ofertados pelo VENDEDOR 
6. Ao descumprimento, pelo VENDEDOR e/ou COMPRADOR, de quaisquer cláusulas e condições das transações de comércio eletrônico, inclusive de prazos de fornecimento e garantia, ou de outras obrigações contratuais ou legais do VENDEDOR

7. Ressalvadas as previsões em sentido contrário constantes deste Instrumento, a qualquer reembolso, devolução de quantias ou pagamento de qualquer indenização ao VENDEDOR e/ou ao COMPRADOR, em razão de reclamações referentes às transações de comércio eletrônico realizadas pelo COMPRADOR.

11.5. O VENDEDOR declara estar ciente de que o serviço prestado pela AKATUS não se destina a ser comparável aos serviços financeiros oferecidos por instituições bancárias ou administradoras de cartão de crédito, constituindo apenas em uma forma de facilitação e acompanhamento da realização de transações comerciais eletrônicas entre compradores e vendedores, ora denominados VENDEDOR E COMPRADOR, mediante serviços de gestão de pagamento, com o pagamento das transações comerciais eletrônicas, por conta e ordem do VENDEDOR.

11.6. O VENDEDOR declara estar ciente de que os serviços a que tiver acesso em decorrência da vigência deste contrato serão para seu uso exclusivo, não podendo os comercializar, repassar ou ceder a terceiros a qualquer título ou os explorar economicamente de qualquer forma.

\section{2 - DISPOSIÇÕES GERAIS}

12.1. Este contrato será regido e interpretado de acordo com as leis da República Federativa do Brasil.

12.2. O VENDEDOR não poderá, em nenhuma hipótese, ceder o presente Instrumento.

12.3. Todas as notificações encaminhadas entre as Partes e serão feitas por meio de correio eletrônico e serão consideradas recebidas 5 (cinco) dias após o seu envio.

12.3.1. Será considerado como e-mail apto para o envio de notificações o e-mail fornecido pelo VENDEDOR quando do seu cadastramento para a utilização da Plataforma de Pagamento.

12.3.2. As notificações encaminhadas para a AKATUS somente serão consideradas válidas se encaminhadas para o e-mail atendimento@akatus.com.

12.4. A AKATUS poderá, a seu critério, conceder ao VENDEDOR condições promocionais para utilização do serviço ora prestados, tais como descontos, reduções temporárias de remuneração, bonificações de remunerações, períodos de testes e ofertas de brindes, cujas regras para fruição estarão disponíveis no site da AKATUS e deverão ser observadas pelo VENDEDOR a partir da contratação dos serviços. A oferta de condições promocionais será considerada mera liberalidade da AKATUS, que as poderá, a qualquer tempo, alterar e retirar, sem que fique caracterizada novação ou renúncia aos direitos ora contratados.

A tolerância de uma parte relativamente ao descumprimento de qualquer das obrigações da outra não será considerada novação ou renúncia a qualquer direito, mas mera liberalidade, que não impedirá a parte tolerante de exigir da outra o seu cumprimento, a qualquer tempo.

12.5. A AKATUS não se responsabiliza pelo pagamento dos tributos devidos pelo 
VENDEDOR e/ou pelo COMPRADOR em razão das operações realizadas com a utilização de sua Plataforma de Pagamentos.

12.6. Eventual suporte técnico e operacional ao serviço ora prestado será realizado diretamente pela AKATUS, ou por terceiro por ela contratado, sob sua responsabilidade, através do link www.akatus.com.br/contato.

12.7. O VENDEDOR não é autorizado a pronunciar-se em nome da AKATUS, devendo direcionar todos os questionamentos, suporte, auxílio ou outras necessidades de comunicação em relação ao serviço ora prestado pela AKATUS para o serviço de atendimento constante do link da cláusula anterior.

12.8. O VENDEDOR autoriza, desde já, o uso de seu logotipo e/ou marca nas campanhas publicitárias desenvolvidas pela AKATUS.

A AKATUS não se responsabiliza por qualquer comunicação ou conteúdo recebido ou acessado pelo VENDEDOR ou pelo COMPRADOR através do Serviço ora prestado, os quais serão de inteira responsabilidade de quem os houver disponibilizado.

12.9. Qualquer omissão ou tolerância das Partes em relação às obrigações assumidas neste instrumento não será considerada novação contratual ou renúncia, nem prejudicará o direito da parte de exercê-las a qualquer tempo.

12.10. E por estarem justas e contratadas, as partes elegem o foro da Comarca de São Paulo, Estado de São Paulo para dirimir qualquer controvérsia oriunda do presente Instrumento, com exclusão de qualquer outro, por mais privilegiado que seja." 


\section{Anexo III}

"Directive 2000/46/EC of the European Parliament and of the Council of 18 September 2000 on the taking up, pursuit of and prudential supervision of the business of electronic money institutions THE EUROPEAN PARLIAMENT AND THE COUNCIL OF THE EUROPEAN UNION, Having regard to the Treaty establishing the European Community, and in particular the first and third sentences of Article 47(2) thereof, Having regard to the proposal from the Commission(1), Having regard to the opinion of the Economic and Social Committee(2), Having regard to the opinion of the European Central Bank(3), Acting in accordance with the procedure laid down in Article 251 of the Treaty(4), Whereas:

(1) Credit institutions within the meaning of Article 1, point 1, first subparagraph (b) of Directive 2000/12/EC(5) are limited in the scope of their activities.

(2) It is necessary to take account of the specific characteristics of these institutions and to provide the appropriate measures necessary to coordinate and harmonise Member States' laws, regulations and administrative provisions relating to the taking up, pursuit and prudential supervision of the business of electronic money institutions.

(3) For the purposes of this Directive, electronic money can be considered an electronic surrogate for coins and banknotes, which is stored on an electronic device such as a chip card or computer memory and which is generally intended for the purpose of effecting electronic payments of limited amounts.

(4) The approach adopted is appropriate to achieve only the essential harmonisation necessary and sufficient to secure the mutual recognition of authorisation and prudential supervision of electronic money institutions, making possible the granting of a single licence recognised throughout the Community and designed to ensure bearer confidence and the application of the principle of home Member State prudential supervision.

(5) Within the wider context of the rapidly evolving electronic commerce it is desirable to provide a regulatory framework that assists electronic money in delivering its full potential benefits and that avoids hampering technological innovation in particular. Therefore, this Directive introduces a technology-neutral legal framework that harmonises the prudential supervision of electronic money institutions to the extent necessary for ensuring their sound and prudent operation and their financial integrity in particular.

(6) Credit institutions, by virtue of point 5 of Annex I to Directive 2000/12/EC, are already allowed to issue and administer means of payment including electronic money and to carry on such activities Community-wide subject to mutual recognition and to the comprehensive prudential supervisory system applying to them in accordance with the European banking Directives.

(7) The introduction of a separate prudential supervisory regime for electronic money institutions, which, although calibrated on the prudential supervisory regime applying to 
other credit institutions and Directive 2000/12/EC except Title V, Chapters 2 and 3 thereof in particular, differs from that regime, is justified and desirable because the issuance of electronic money does not constitute in itself, in view of its specific character as an electronic surrogate for coins and banknotes, a deposit-taking activity pursuant to Article 3 of Directive 2000/12/EC, if the received funds are immediately exchanged for electronic money.

(8) The receipt of funds from the public in exchange for electronic money, which results in a credit balance left on account with the issuing institution, constitutes the receipt of deposits or other repayable funds for the purpose of Directive 2000/12/EC.

(9) It is necessary for electronic money to be redeemable to ensure bearer confidence. Redeemability does not imply, in itself, that the funds received in exchange for electronic money shall be regarded as deposits or other repayable funds for the purpose of Directive 2000/12/EC.

(10) Redeemability should always be understood to be at par value.

(11) In order to respond to the specific risks associated with the issuance of electronic money this prudential supervisory regime must be more targeted and, accordingly, less cumbersome than the prudential supervisory regime applying to credit institutions, notably as regards reduced initial capital requirements and the non-application of Directive 93/6/EEC(6) and Title V, Chapter 2, Sections II and III of Directive 2000/12/EC.

(12) However, it is necessary to preserve a level playing field between electronic money institutions and other credit institutions issuing electronic money and, thus, to ensure fair competition among a wider range of institutions to the benefit of bearers. This is achieved since the abovementioned less cumbersome features of the prudential supervisory regime applying to electronic money institutions are balanced by provisions that are more stringent than those applying to other credit institutions, notably as regards restrictions on the business activities which electronic money institutions may carry on and, particularly, prudent limitations of their investments aimed at ensuring that their financial liabilities related to outstanding electronic money are backed at all times by sufficiently liquid low risk assets.

(13) Pending the harmonisation of prudential supervision of outsourced activities for credit institutions it is appropriate that electronic money institutions have sound and prudent management and control procedures. With a view to the possibility of operational and other ancilliary functions related to the issuance of electronic money being performed by undertakings which are not subject to prudential supervision it is essential that electronic money institutions have in place internal structures which should respond to the financial and non-financial risks to which they are exposed.

(14) The issuance of electronic money may affect the stability of the financial system and the smooth operation of payments systems. Close cooperation in assessing the integrity of electronic money schemes is called for. 
(15) It is appropriate to afford competent authorities the possibility of waiving some or all of the requirements imposed by this Directive for electronic money institutions which operate only within the territories of the respective Member States.

(16) Adoption of this Directive constitutes the most appropriate means of achieving the desired objectives. This Directive is limited to the minimum necessary to achieve these objectives and does not go beyond what is necessary for this purpose.

(17) Provision should be made for the review of this Directive in the light of experience of developments in the market and the protection of bearers of electronic money.

(18) The Banking Advisory Committee has been consulted on the adoption of this Directive,

\section{HAVE ADOPTED THIS DIRECTIVE:}

\section{Article 1 - Scope, definitions and restriction of activities}

1. This Directive shall apply to electronic money institutions.

2. It shall not apply to the institutions referred to in Article 2(3) of Directive 2000/12/EC.

3. For the purposes of this Directive:

(a) "electronic money institution" shall mean an undertaking or any other legal person, other than a credit institution as defined in Article 1, point 1, first subparagraph (a) of Directive 2000/12/EC which issues means of payment in the form of electronic money;

(b) "electronic money" shall mean monetary value as represented by a claim on the issuer which is:

(i) stored on an electronic device;

(ii) issued on receipt of funds of an amount not less in value than the monetary value issued;

(iii) accepted as means of payment by undertakings other than the issuer.

4. Member States shall prohibit persons or undertakings that are not credit institutions, as defined in Article 1, point 1, first subparagraph of Directive 2000/12/EC, from carrying on the business of issuing electronic money.

5. The business activities of electronic money institutions other than the issuing of electronic money shall be restricted to:

(a) the provision of closely related financial and non-financial services such as the administering of electronic money by the performance of operational and other ancillary functions related to its issuance, and the issuing and administering of other means of payment but excluding the granting of any form of credit; and

(b) the storing of data on the electronic device on behalf of other undertakings or public institutions.

Electronic money institutions shall not have any holdings in other undertakings except where these undertakings perform operational or other ancillary functions related to electronic money issued or distributed by the institution concerned. 


\section{Article 2 - Application of Banking Directives}

1. Save where otherwise expressly provided for, only references to credit institutions in Directive 91/308/EEC(7) and Directive 2000/12/EC except Title V, Chapter 2 thereof shall apply to electronic money institutions.

2. Articles 5, 11, 13, 19, 20(7), 51 and 59 of Directive 2000/12/EC shall not apply. The mutual recognition arrangements provided for in Directive 2000/12/EC shall not apply to electronic money institutions' business activities other than the issuance of electronic money.

3. The receipt of funds within the meaning of Article 1(3)(b)(ii) does not constitute a deposit or other repayable funds according to Article 3 of Directive 2000/12/EC, if the funds received are immediately exchanged for electronic money.

\section{Article 3 - Redeemability}

1. A bearer of electronic money may, during the period of validity, ask the issuer to redeem it at par value in coins and bank notes or by a transfer to an account free of charges other than those strictly necessary to carry out that operation.

2. The contract between the issuer and the bearer shall clearly state the conditions of redemption.

3. The contract may stipulate a minimum threshold for redemption. The threshold may not exceed EUR 10.

\section{Article 4 - Initial capital and ongoing own funds requirements}

1. Electronic money institutions shall have an initial capital, as defined in Article 34(2), subparagraphs (1) and (2) of Directive 2000/12/EC, of not less than EUR 1 million. Notwithstanding paragraphs 2 and 3, their own funds, as defined in Directive 2000/12/EC, shall not fall below that amount.

2. Electronic money institutions shall have at all times own funds which are equal to or above $2 \%$ of the higher of the current amount or the average of the preceding six months' total amount of their financial liabilities related to outstanding electronic money.

3. Where an electronic money institution has not completed a six months' period of business, including the day it starts up, it shall have own funds which are equal to or above $2 \%$ of the higher of the current amount or the six months' target total amount of its financial liabilities related to outstanding electronic money. The six months' target total amount of the institution's financial liabilities related to outstanding electronic money shall be evidenced by its business plan subject to any adjustment to that plan having been required by the competent authorities.

\section{Article 5 - Limitations of investments}

1. Electronic money institutions shall have investments of an amount of no less than their financial liabilities related to outstanding electronic money in the following assets only:

(a) asset items which according to Article 43(1)(a) (1), (2), (3) and (4) and Article 44(1) of Directive 2000/12/EC attract a zero credit risk weighting and which are sufficiently liquid; 
(b) sight deposits held with Zone A credit institutions as defined in Directive 2000/12/EC; and

(c) debt instruments which are:

(i) sufficiently liquid;

(ii) not covered by paragraph 1 (a);

(iii) recognised by competent authorities as qualifying items within the meaning of Article 2(12) of Directive 93/6/EEC; and

(iv) issued by undertakings other than undertakings which have a qualifying holding, as defined in Article 1 of Directive 2000/12/EC, in the electronic money institution concerned or which must be included in those undertakings' consolidated accounts.

2. Investments referred to in paragraph 1(b) and (c) may not exceed 20 times the own funds of the electronic money institution concerned and shall be subject to limitations which are at least as stringent as those applying to credit institutions in accordance with Title V, Chapter 2, Section III of Directive 2000/12/EC.

3. For the purpose of hedging market risks arising from the issuance of electronic money and from the investments referred to in paragraph 1, electronic money institutions may use sufficiently liquid interest-rate and foreign-exchange-related off balance-sheet items in the form of exchange-traded (i.e. not OTC) derivative instruments where they are subject to daily margin requirements or foreign exchange contracts with an original maturity of 14 calendar days or less. The use of derivative instruments according to the first sentence is permissible only if the full elimination of market risks is intended and, to the extent possible, achieved.

4. Member States shall impose appropriate limitations on the market risks electronic money institutions may incur from the investments referred to in paragraph 1.

5. For the purpose of applying paragraph 1, assets shall be valued at the lower of cost or market value.

6. If the value of the assets referred to in paragraph 1 falls below the amount of financial liabilities related to outstanding electronic money, the competent authorities shall ensure that the electronic money institution in question takes appropriate measures to remedy that situation promptly. To this end, and for a temporary period only, the competent authorities may allow the institution's financial liabilities related to outstanding electronic money to be backed by assets other than those referred to in paragraph 1 up to an amount not exceeding the lower of $5 \%$ of these liabilities or the institution's total amount of own funds.

\section{Article 6 - Verification of specific requirements by the competent authorities}

The competent authorities shall ensure that the calculations justifying compliance with Articles 4 and 5 are made, not less than twice each year, either by electronic money institutions themselves, which shall communicate them, and any component data required, to the competent authorities, or by competent authorities, using data supplied by the electronic money institutions.

\section{Article 7 - Sound and prudent operation}

Electronic money institutions shall have sound and prudent management, administrative and accounting procedures and adequate internal control mechanisms. These should respond to 
the financial and non-financial risks to which the institution is exposed including technical and procedural risks as well as risks connected to its cooperation with any undertaking performing operational or other ancillary functions related to its business activities.

\section{Article 8 - Waiver}

1. Member States may allow their competent authorities to waive the application of some or all of the provisions of this Directive and the application of Directive 2000/12/EC to electronic money institutions in cases where either:

(a) the total business activities of the type referred to in Article 1(3)(a) of this Directive of the institution generate a total amount of financial liabilities related to outstanding electronic money that normally does not exceed EUR 5 million and never exceeds EUR 6 million; or

(b) the electronic money issued by the institution is accepted as a means of payment only by any subsidiaries of the institution which perform operational or other ancillary functions related to electronic money issued or distributed by the institution, any parent undertaking of the institution or any other subsidiaries of that parent undertaking; or

(c) electronic money issued by the institution is accepted as payment only by a limited number of undertakings, which can be clearly distinguished by:

(i) their location in the same premises or other limited local area; or

(ii) their close financial or business relationship with the issuing institution, such as a common marketing or distribution scheme.

The underlying contractual arrangements must provide that the electronic storage device at the disposal of bearers for the purpose of making payments is subject to a maximum storage amount of not more than EUR 150.

2. An electronic money institution for which a waiver has been granted under paragraph 1 shall not benefit from the mutual recognition arrangements provided for in Directive 2000/12/EC.

3. Member States shall require that all electronic money institutions to which the application of this Directive and Directive 2000/12/EC has been waived report periodically on their activities including the total amount of financial liabilities related to electronic money.

\section{Article 9 - Grandfathering}

Electronic money institutions subject to this Directive which have commenced their activity in accordance with the provisions in force in the Member State in which they have their head office before the date of entry into force of the provisions adopted in implementation of this Directive or the date referred to in Article 10(1), whichever date is earlier, shall be presumed to be authorised. The Member States shall oblige such electronic money institutions to submit all relevant information to the competent authorities in order to allow them to assess within six months from the date of entry into force of the provisions adopted in implementation of this Directive, whether the institutions comply with the requirements pursuant to this Directive, which measures need to be taken in order to ensure compliance, or whether a withdrawal of authorisation is appropriate. If compliance is not ensured within six months from the date referred to in Article 10(1), the electronic money institution shall not benefit from mutual recognition after that time. 


\section{Article 10 - Implementation}

1. Member States shall bring into force the laws, regulations and administrative provisions necessary to comply with this Directive not later than 27 April 2002. They shall immediately inform the Commission thereof.

When Member States adopt these measures, they shall contain a reference to this Directive or shall be accompanied by such reference on the occasion of their official publication. The methods of making such a reference shall be laid down by the Member States.

2. Member States shall communicate to the Commission the text of the main provisions of national law, which they adopt in the field covered by this Directive.

\section{Article 11 - Review}

Not later than 27 April 2005 the Commission shall present a report to the European Parliament and the Council on the application of this Directive, in particular on:

- the measures to protect the bearers of electronic money, including the possible need to introduce a guarantee scheme,

- capital requirements,

- waivers, and

- the possible need to prohibit interest being paid on funds received in exchange for electronic money,

accompanied where appropriate by a proposal for its revision.

\section{Article 12 - Entry into force}

This Directive shall enter into force on the day of its publication in the Official Journal of the European Communities.

\section{Article 13}

This Directive is addressed to the Member States.

Done at Brussels, 18 September 2000.

For the European Parliament

The President" 